Historic, Archive Document

Do not assume content reflects current scientific knowledge, policies, or practices. 

62.13

tyill of Yracy on

GLISWW ANNUAL SEED CATALOG FOR 1910

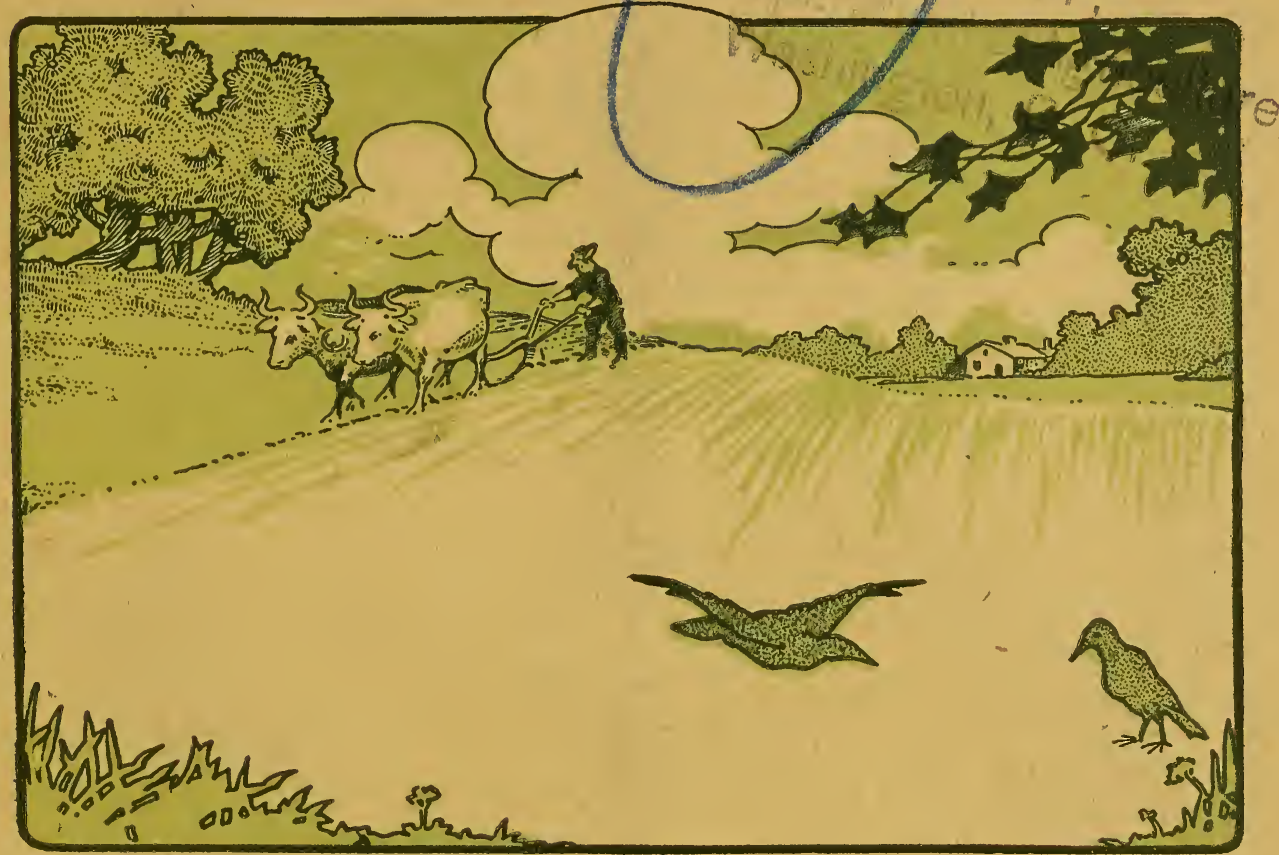

\section{HIGHEST GRADE}
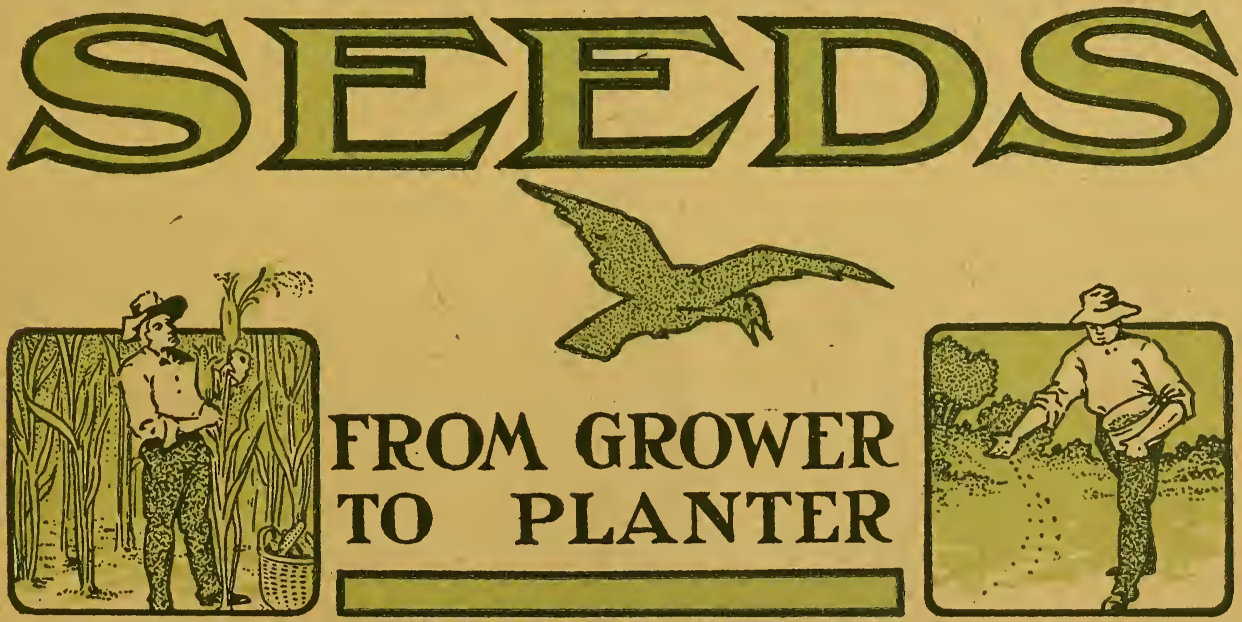

FROM GROWER 2 2 in TO PLANTER

THOS. GRISWOLD \& COSOUTH WETHERSTIELD, CONN. 


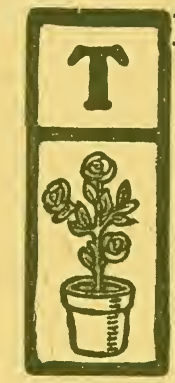

HIS is practically a wholesale price list of first quality seeds direct from growers to planters. If the party receiving this catalogue has never planted our seeds we would simply ask that you send us a trial order and let the seeds speak for themselves which we think is the best and most convincing way of showing that our seeds are first class.

Our catalogues are free to your friends. Send in names and we will mail the catalogues.

\section{政的}

Some of our callers in the past have found difficulty in reaching us as they have taken the wrong trolley line, so we will state that our office and warehouse is about six miles south of Hartford near Station 23, Hartford and Middletown trolley.

We are glad to have parties call that find it converient to do so. 


\section{Mr. Seed Planter}

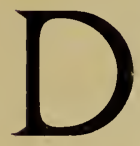

ID you ever stop to consider the fact that the more direct you purchase your goods from the producer or grower the more likely you are to get a better and fresher article and at a more reasonable price. You save the cost of handling the goods and dealers' profits. Is not this a fact?

Many of the seeds sold to-day are handled by from two to five parties before they reach the planter, consequently the planter pays several profits more than is necessary and he does not always get a fresh article.

While we have grown seeds extensively for years we do not claim to grow all varieties as some cannot be grown to perfection under New England climatical conditions and such varieties we have grown for us, under contracts, by growers that make specialties of growing varieties we want.

We do business in the country-owning our seed farms and buildings, and consequently are not under the heary expense many seedmen are, and we can make prices very reasonable.

We shall be pleased to receive your orders.

Respectfully yours, 


\section{A REQUEST}

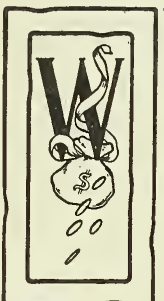

E appreciate the fact that many do not know just what they want in the SEED LINE until about planting time, consequently. many orders are delayed until late, and then come in a rush, fairly covering us up and it is almost impossible to keep up with the orders; so if our patrons that can, will kindly send in their orders as early as convenient we will greatly appreciate it.

THOS. GRISWOLD \& CO. 


\section{January 15, 1910. \\ THOMAS GRISWOLD \& CO., \\ South Wethersfield, Conn.}

\section{TERMS.}

We make our prices so low that we can afford to give credit only to reliable parties well known to us and only in limited amounts, and when credit is allowed accounts will be subject to interest at the rate of six per cent. per annum. By doing principally a cash with order business we run little risk and can make very reasonable prices which is a benefit to our customers. Out-standing bills are due June Ist, I9IO, unless otherwise agreed.

How to send money.-Remit by Post Office or Express Money Order, Registered Mail or Bank Draft. Postage Stamps may be sent for small amounts. Personal Checks accepted from parties having established credit.

Post Office Money Orders should be made payable at South Wethersfield.

When Seeds are Wanted by Mail, postage must be added at the rate of 8 cents per pound for Seeds, (except flower seeds), ro cents per quart for Corn and Onion Sets, and 15 cents per quart for Beans and Peas.

Bags, barrels, etc., free of charge. No charge for cartage.

Purchasers pay express and freight charges unless otherwise agreed.

Shipping Instructions should accompany each order. If no such instructions are received we will ship by the best and cheapest route known to us.

After shipping in good order our responsibility ceases, claims for damages or miscarriage must be laid on the carriers.

Parties purchasing from us, and wishing references as to our business integrity are respectfully referred to R. G. Dun \& Co's, and Bradstreet's Mercantile Agencies, also to our Postmaster, or Town Officers.

As so much depends upon the condition of the weather, soil, etc. when seeds are planted and the care taken in planting them, we sell our goods, in common with other reliable seed houses, subject to the following disclaimer adopted by the American Seed Trade Association.

Disclaimer,-We give no warranty, express or implied as to description, quality, productiveness or any other matter of any seeds, bulbs or plants we send out and will not be in any way responsible for the crop. If the purchaser does not accept the goods on these terms they are at once to be returned. 


\section{ASPARAGUS.}

Conover's Colossal. A standard variety,

Barr's Philadelphia Mammoth. Large, uniform and tender,

Palmetto. Early. large. bright green.

Early Giant Argenteuil. Extra large, fine,

\section{Asparagus Roots.}

Conover's Colossal,

\section{Strong, Thrifty-Two=Years Old Roots}

Palmetto,

Barr's Philadelphia Mammoth,

Early Giant Argenteuil,

\section{BEANS. - Dwarf Green Podded.}

Extra Early Refugee. Two weeks earlier than the rommon Refugee, more Dwarf; and compact in habit of growth, pods whitish green, round and tender,

Full Measure. Round green pod, medium early and stringless.

Early Long Yellow, Six Weeks. Early, light green, straight, flat pod,

Bountiful. Should be classed as stringless six weeks, upright in growth, healthy, vigorous and very productive. Pods light green, long, flat and stringless,

Improved Early Round Pod Valentine. Good, extra early, green pod,

Black Valentine. A hardy, blight resisting variety, early, and productive of long, round, flat green pods which are tender when voung,

Stringless, Green Pod(Burpee's). Early, productive, very hardy,

Low's Champion. Green podded, large, very prolific, . .

Refugee or Thousand To One. Old standard, medium early, .

Dwarf Horticultural. Yellowish pod, splashed with red; excellent,

Goddard or Boston Favorite. Large vines, long, large, flat pods; green, crimson striped,

White Kidney. Long, white soup bean, .

Large White Marrow. Excellent for cooking, when dry, .

Boston Small Pea Bean. Fine for soups and baking,

\section{Wax or Butter Varieties.}

Golden Eyed Wax. White bean with yellow eye; early and hardy, pods long, straight, flat, fair quality,

Improved Rust Proof Golden Wax. Improved strain of Golden Wax, pods straight, flatish, golden yellow color, . .

Currie's Rust Proof Black Wax. Yellow, flat pods; hardy and early,

Prolific Black Wax. More productive than common Black Wax,

Pencil Pod Black Wax. A very fine strain of Black Wax and popular with many Gardeners. Vine is of bushy character and prolific. Pods long, round, straight, and rich yellow color,

Wardwell's Kidney Wax. Large, flat, yellow pod, and early, Refugee Wax. A very productive yellow podded variety,

Yosemite Mammoth Black Wax. Mammoth, long, yellow pods, fine quality,

Davis' White Kidney Wax. Extremely hardy and good keeping quality,

Valentine Wax. Round, meaty, yellow pods, excellent, .
Per oz. Per $1 / 4 \mathrm{lb}$. Per $1 \mathrm{~b}$.

\$O 05 \$O 15 \$O 30

$5 \quad$ I5 40

$5 \quad \mathrm{I} 5$

5

20

40

60

or 5 more

Per 1b.

\$o 25

35

35

55

$\begin{array}{clr}\text { Per 100 } & \text { Per } 5 c 0 & \text { Per } 1.000 \\ 50 & 200 & 350 \\ 55 & 225 & 375 \\ 55 & 225 & 375 \\ 60 & 250 & 400\end{array}$

Per quart. 4 quarts. Per peck. Per bu.

\begin{tabular}{|c|c|c|c|c|}
\hline \$o 20 & $\$ 065$ & \$I & IO & $\$ 4$ \\
\hline 20 & 65 & I & IO & 4 \\
\hline 20 & 55 & I & $\mathrm{OO}$ & 3 \\
\hline 20 & 65 & I & IO & \\
\hline 20 & 60 & I & $\mathrm{OO}$ & 3 \\
\hline 20 & 65 & I & IO & 4 \\
\hline 20 & 70 & I & 20 & 4 \\
\hline 20 & 70 & I & 20 & 4 \\
\hline 20 & 65 & I & IO & 4 \\
\hline 20 & 70 & I & I 5 & t \\
\hline 20 & 70 & I & IO & 4 \\
\hline I 5 & 55 & & 90 & 3 \\
\hline I 5 & 55 & & 90 & 3 \\
\hline $\mathrm{I} 5$ & 55 & & 90 & \\
\hline
\end{tabular}

\begin{tabular}{|c|c|c|}
\hline 25 & 75 & I 30 \\
\hline 25 & 80 & I 40 \\
\hline & 75 & I 30 \\
\hline & 75 & I 30 \\
\hline
\end{tabular}


Dwarf or Bush Lima Beans.

Henderson's Bush Lima. A small, low lima, .

Burpee's Bush Lima. Dwarf vine ; large flat beans,

Thorburn's or Dreer's Bush Lima. Roundish white beans; fine quality,

Burpee's Improved Bush Lima. A distinct improvement in bush limas having much larger and uniform pods filled with extra large beans of fine quality, and is extra early and very prolific,

Fordhook Bush Lima. A much improved type of Dreer's Bush Lima. The plant is of stiff upright growth, branching freely and great yielder of pods well filled with thick, luscious beans,

\section{Pole or Running Varieties.}

White Creaseback. A prolific, round, green podded bean. The pods are borne in clusters, are stringless, and of excellent quality,

Early Dutch Case Knife. Very early; flat, green pod,

Horticultural or Cranberry Pole. Long, green pod ; red striped,

Extra Early Jersey Lima. One of the best early limas, .

Siebert's Early, large lima, similar to the above, but larger pods,

King of Garden Lima. Early, productive, large podded variety,

Extra Large Lima. Very large, late lima,

Large Lima or Butter. Common variety,

Challenger Lima. Similar to Dreer's Improved,

Dreer's Improved Lima. Fine quality and early, beans nearly round.

Kentucky Wonder (Old Homestead), Stringless. Long bright green pods; tender; grow in clusters and very productive.

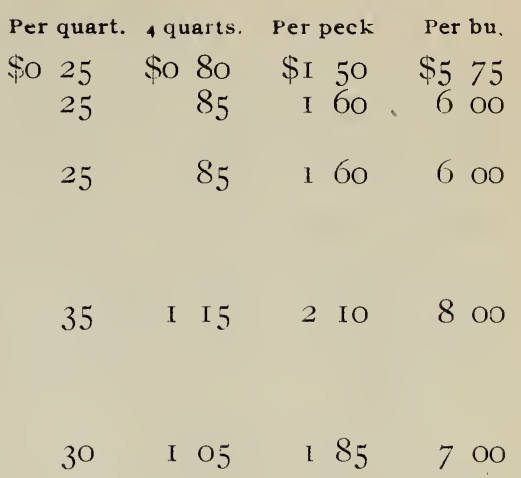

$\begin{array}{llllll}25 & 85 & \mathrm{I} & 5 \mathrm{O} & 5 & 5 \mathrm{O} \\ 25 & 75 & \mathrm{I} & 30 & 4 & 50 \\ 25 & 75 & \mathrm{I} & 35 & 5 & \mathrm{OO} \\ 25 & 75 & \mathrm{I} & 35 & 5 & 25 \\ 25 & 75 & 1 & 35 & 5 & 25 \\ 25 & 75 & \mathrm{I} & 35 & 5 & 25 \\ 25 & 75 & \mathrm{I} & 35 & 5 & 25 \\ 25 & 75 & \mathrm{I} & 35 & 5 & 25 \\ 25 & 75 & \mathrm{I} & 35 & 5 & 25 \\ 25 & 75 & \mathrm{I} & 35 & 5 & 25 \\ 25 & 75 & 1 & 30 & +50\end{array}$

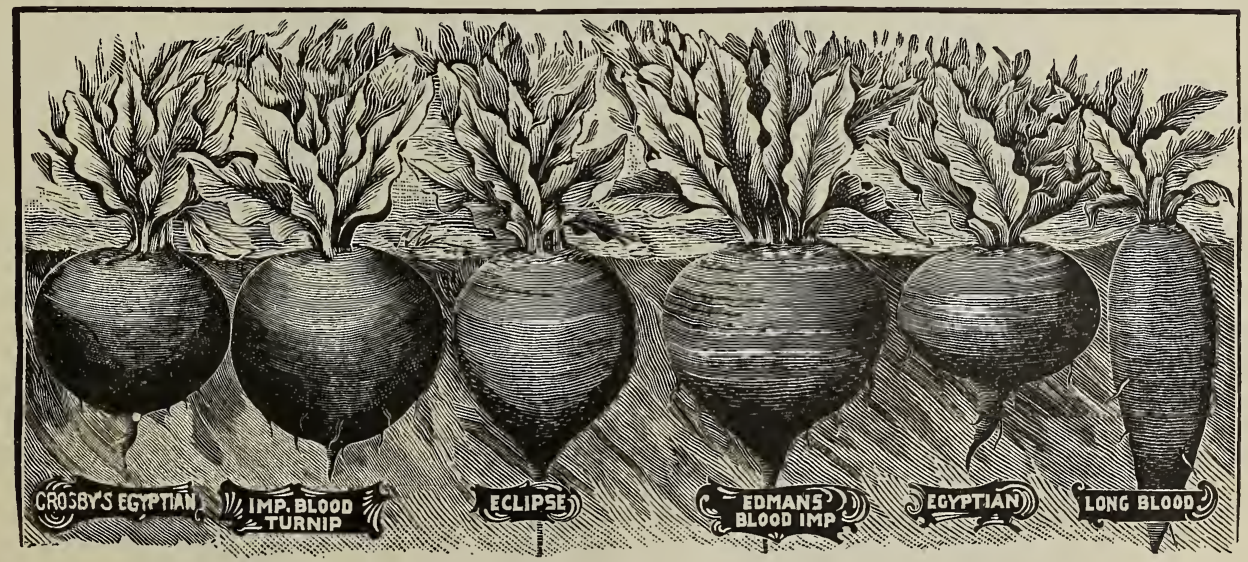

\section{BEETS. - Garden Varieties.}

Fire Ball. Early, globe shaped, flesh blood red and fine quality,

Crosby's Egyptian Turnip. Improved strain of the Old Egyptian; thicker beet,

Early Egyptian Turnip. Quick growing flat variety,

Early Eclipse. Smallish round, red beet; excellent,

Columbia (Burpee's). Round, deep red; fine quality.

$\begin{array}{rrrr}\text { Per oz. } & \text { Per } 1 / 41 \mathrm{~b} . & \text { Per 1b } & \begin{array}{c}5 \text { lbs. } \\ \text { or more } \\ \text { Per } 1 \mathrm{~b} .\end{array} \\ \text { \$O O5 } & \text { \$O } 2 \mathrm{O} & \text { \$O } 60 & \text { \$O } 55 \\ & & & \\ 5 & 15 & 5 \mathrm{O} & 45 \\ 5 & \mathrm{I} 5 & 35 & 32 \\ 5 & \mathrm{I} 5 & 35 & 32 \\ 5 & \text { I } 5 & 40 & 35\end{array}$


BEETS.-Garden Varieties.-Continued.

Detroit Dark Red. Early, small tops, dark red,

Extra Early Dirigo. One of the earliest ; fine quality, •

Early Crimson Globe. Very early, globe shape; flesh deep red,

Edmand's Early Turnip. The best for late planting; blood red and sweet,

Swiss Chard. For greens,

Arlington Early Blood Turnip. An excellent strain of blood turnip,

Improved Early Blood Turnip. Improvement on the old strain, fine stock, .

Bastian's Early Blood Turnip. A good, extra early strain, .

Long, smooth, Dark Red. Fine grained, long deep red beet,

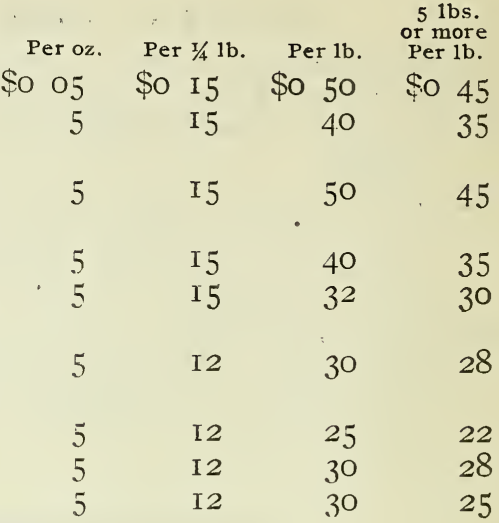

\section{MANGEL BEETS.-For Stock Feeding.}

Red Globe Mangel. Medium size, globe shape,

Long Red Mangel. One of the best for stock, .

Mammoth Long Red Mangel. Very large, great yielder,

Golden Tankard. Short, thick, yellow mangel,

Yellow Globe Mangel. Not very large, good quality. . .

French White Sugar. A good small beet for stock, sweet, .

Lane's White Sugar. Improvement on French White Sugar, .

\section{BRUSSELS SPROUTS.}

Paris Market. Dwarf variety, excellent, .

Long Island Strain. Favorite in New York market.

IO

\section{CABBAGE.}

We have a large Market Gardeners' trade on cabbage and furnish the finest stocks possible.

Extra Early Express. A small, extra early cabbage, pointed head,

Early Spring. The earliest flat head variety, and large,

Early Eureka. This is really a flat headed Jersey Wakefield

(1)

\begin{tabular}{|c|c|c|c|c|}
\hline ס & \$o 30 & $\$ I$ & oo & \$o 90 \\
\hline I 5 & 45 & I & 60 & I 50 \\
\hline 20 & 60 & 2 & $\mathrm{OO}$ & I 90 \\
\hline 20 & 50 & I & 75 & I \\
\hline 20 & 50 & I & 75 & I \\
\hline 10 & 30 & I & OO & \\
\hline I 5 & 40 & I & 50 & I \\
\hline 15 & 40 & I & 50 & I \\
\hline & 45 & I & 60 & I \\
\hline
\end{tabular}

Early Jersey Wakefield. A fair size. Early, peaked head,

Large Jersey Wakefield or Charleston. Larger than the Early Jersey Wakefield,

Early Winningstadt. Small pointed head, imported cabbage,

Early Flat Dutch. A very popular early flat head sort, .

Henderson's Early Summer. Similar to Early Flat Dutch, .

All Head. Early. large, flat head cabbage,

All Head. (Special Strain). This is an improved strain that

has been developed more particularly for the Long Island

Market Gardeners' trade and is considered a very fine strain,

Henderson's Succession. A good second early flat head sort, Fottler's Improved Brunswick. Old reliable standard flat head, Surehead. Large, uniform, solid head; sure header, . . All Seasons or Vandergaw. Fine, large, quick heading sort, .

Premium Late Flat Dutch. The old popular variety, for autumn and winter,

Autumn King or World Beater. Very large solid heads,

Danish Ball Head or Hollander. Very hard, small, round head. Excellent keeper,

Volga. Round, solid, uniform head; medium late, fine strain,

\begin{tabular}{|c|c|c|c|}
\hline 20 & 60 & 200 & I \\
\hline 15 & 45 & I 60 & I \\
\hline 15 & 35 & I 30 & I \\
\hline I 5 & 45 & I 60 & I \\
\hline I 5 & 45 & I 60 & I \\
\hline 10 & 35 & I 30 & I \\
\hline & 40 & 140 & I \\
\hline & 45 & I 75 & \\
\hline & & & \\
\hline
\end{tabular}


CABBAGE-Continued.

Red Dutch Pickling. A hard headed, red pickling cabbage,

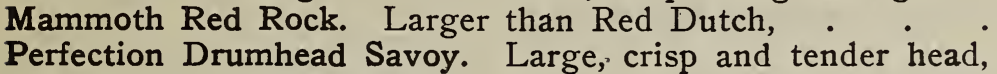
curled or crumpled leaves,

\section{CARROT.}

Early Scarlet Horn. A short, early variety,

Ox-Heart or Guerande. One of the earliest, heart shape, .

Improved Long Orange. The old standard, more for stock feeding,

Improved Danvers Orange. Excellent, stump-rooted sort, .

Danvers Half Long Pointed. Medium long, scarlet, tapering root,

Half Long Nantes. Stump-rooted, little smaller than Improved Danvers,

Chantenay. A short chunked carrot, good for table,

Rubicon. Fine, half-long market variety,

\section{CAULIFLOWER. - Selected.}

Henderson's Early Snowball. One of the best for market,

Extra Early Dwarf Erfurt. Early, of dwarf habit, excellent, .

Le Normand's Short Stem. Large, close heads,

Early Paris. Good quality, medium large heads, : . .

Algiers. Vigorous growth, large head, late,
Per oz. Per $1 / 41 \mathrm{~b}$. Per $1 \mathrm{~b}$ or more

Per 1b.

\$o 90

I 40

I 50

45

Per $1 / 4$ oz. Per $1 / 2$ oz. Per oz. Per $1 / 41 \mathrm{~b}$.

\$o 50 \$o 95 \$I 75 \$6 50

$40 \quad 75 \quad$ I $30 \quad 5$ OO

$25 \quad 40 \quad 60 \quad 225$

$20 \quad 35 \quad 55 \quad 200$

$25 \quad 40 \quad 60 \quad 225$

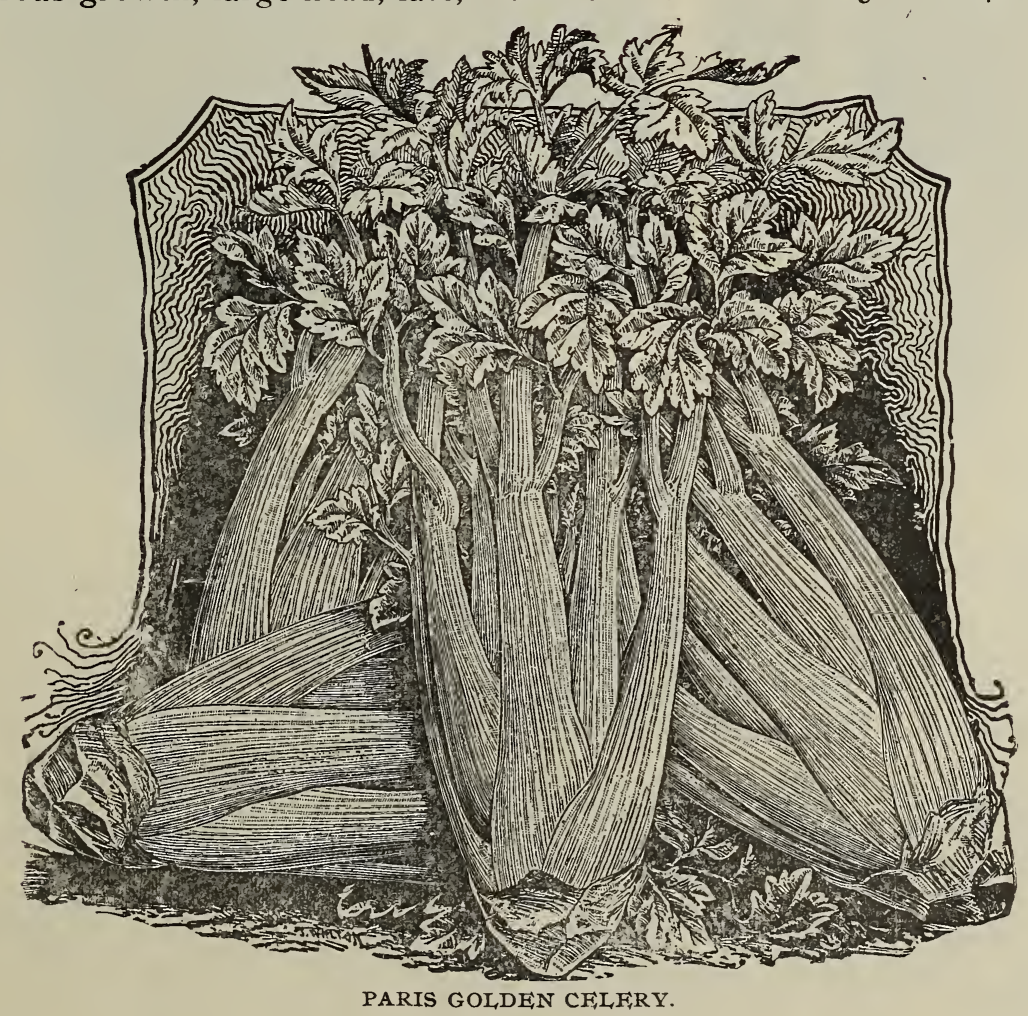

CELERY.

Paris Golden. Self blanching. Finest French grown. (Originators stock).

We import this strain direct from the originators in Paris and highly recommend

it. Per oz., 25 c., per $1 / 4$ lb., 85 c., per lb., $\$ 3.25,5 \mathrm{lbs}$. or more, $\$ 3.00$ per $\mathrm{lb}$. 


\section{CELERY - Continued.}

White Plume. Self bleaching, .

Giant Pascal. Excellent green variety, crisp and tender, fine keeper, $\dot{0} \dot{0}$ ection Heartwell. Golden yellow hearted, superior quality,

Golden Heart Dwarf. Old standard, fine flavor, Crawford's or Henderson's Half Dwarf. Medium size, yellowish white,

Boston Market. One of the old reliable sorts,

Shumacher. Very large yellow heart, nutty flavor, crisp, .

Winter Queen. Finest winter variety, long keeper,

Celeriac. Large, smooth sprague, turnip-rooted celery, .
$51 \mathrm{bs}$.
or more

Per 1b. Per 1b.

\$I 30

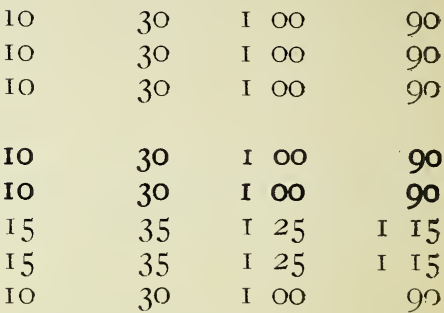

\section{CORN SALAD.}

Broad Leaved. A good substitute for lettuce in winter, . . $\quad \begin{array}{lllll}5 & \text { I } 5 & 40 & 35\end{array}$

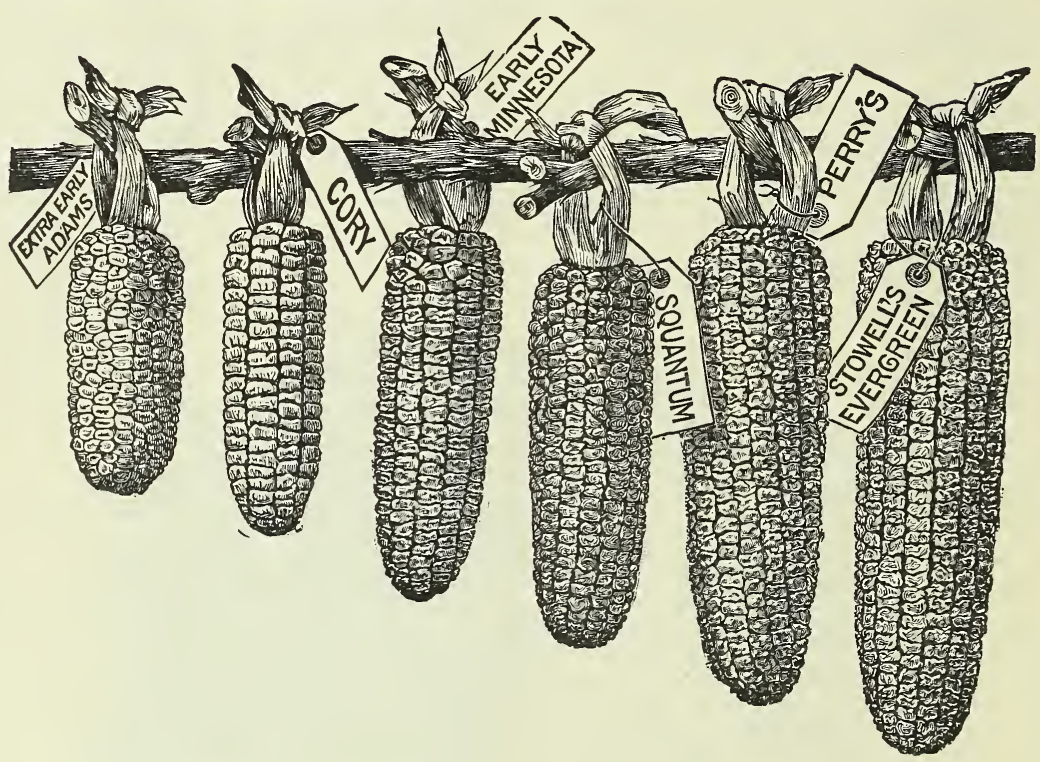

\section{SWEET CORN.}

There is no Sweet Corn grown that will equal in quality the Corn grown in New England. Our Stock is fine.

Golden Bantam. A beautiful golden yellow variety of fine, sweet flavor, very early, productive and excellent quality, and is fast coming to the front where known, . . .

Extra Early Red Cory. Very early, large kernel, medium size red cob, .

Extra Early White Cory. Like the above only white, . Burbank's Early Maine. Improved White Cory,

Mammoth White Cory. About as early and larger than White Cory,

Cosmopolitan. One of the best Early Large Eared varieties, Early Minnesota. Early variety and good quality, .

Early Metropolitan. Large, second early, white ears, io to 12 inches,

Early Champion. Large ear, white grain, early, market gardener's favorite,

Crosby's Early. No better corn grows, for second early, .

Perry's Hybrid. Sweet, tender, good sized ear, second early, .
Per quart. 4 quarts. Per peck. Per bu.

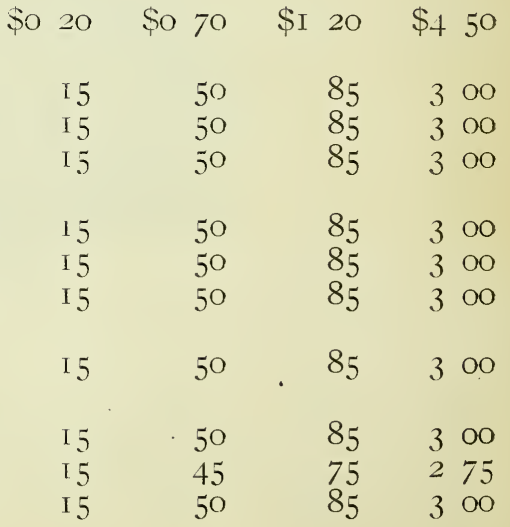




\section{SWEET CORN.-Continued.}

Black Mexican. Black kernel, fair sized ear, second early, fine quality,

Russell's Prolific. Medium early of excellent quality, ${ }^{\circ}$ Moore's Early Concord. Thick ear, good size, fine quality, . Early Evergreen. About Io days earlier than Stowell's Evergreen,

Potter's Excelsior or Squantum. Second early, very sweet,

Early Mammoth. Long, slim ear, about two weeks earlier than Late Mammoth, .

Stowell's Evergreen. Old and tried variety,

Shoe Peg. Long, slim kernel, ears medium size, very sweet; late,

Country Gentleman. Little larger than Shoe Peg, . :

Late Mammoth. Very large white ears and late, . .

For Field and Ensilage Corn, see pages 22 and 23.

\section{CRESS.}

Extra Curled. Quick growing, .

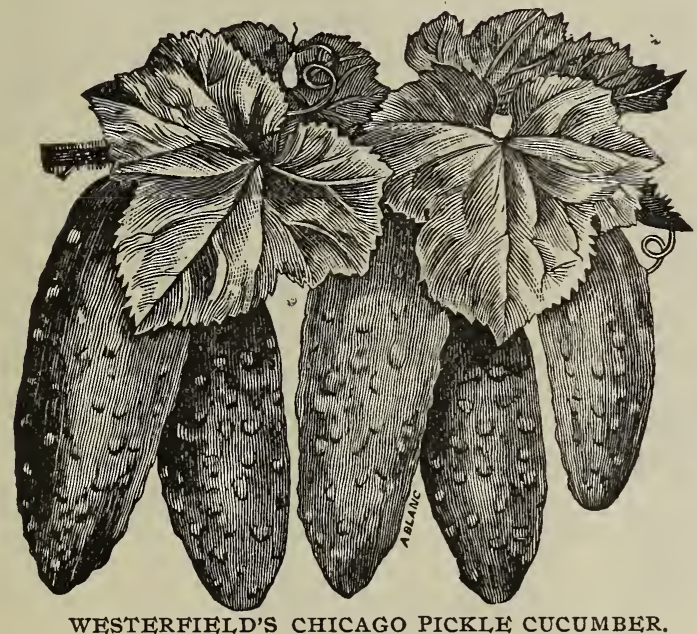

\section{CUCUMBER}

Davis' Perfect. A beautiful dark green variety, handsome shape and enormous producer; excellent for either forcing or out door culture,

Klondike. A strain of White Spine with dark green skin and extra fine quality,

Arlington White Spine. A superior strain for forcing, .

Peerless White Spine. Early, handsome, fine cucumber, .
Improved Early White Spine. Med. length, early, tender and crisp,

Extra Long White Spine. Long, slender, excellent for pickles,

Thorburn's Everbearing. Early and productive, small,

Early Cluster. Medium size, productive, cucumbers clustering about the hill,

Early Short Green. Oid familiar variety, . $\quad . \quad$. $\quad$.

Nichol's Medium Green. Improved short green, .

Green Prolific. Uniform size, dark green, nice for early pickles,

Boston Pickling. A great favorite in Boston market,
Perquart. 4 quarts. Per peck. Perbu

\begin{tabular}{|c|c|c|c|}
\hline 020 & $\$ 060$ & \$o 95 & $\$ 350$ \\
\hline 15 & 50 & 85 & 300 \\
\hline I 5 & 50 & 85 & 300 \\
\hline I 5 & $5^{\circ}$ & 85 & 300 \\
\hline 20 & 60 & 95 & 350 \\
\hline${ } 5$ & 50 & 85 & 300 \\
\hline 20 & 60 & 95 & 350 \\
\hline I5 & $5^{\circ}$ & 85 & 300 \\
\hline 20 & 60 & 95 & 350 \\
\hline 20 & 60 & 95 & 350 \\
\hline 20) & 60 & 95 & $35^{\circ}$ \\
\hline
\end{tabular}

Per oz. Per $1 / 4$ lb. Per lb. $\begin{array}{r}51 \mathrm{bs} . \\ \text { or more }\end{array}$

\$0 05 \$O 10 \$o 25 \$O 20

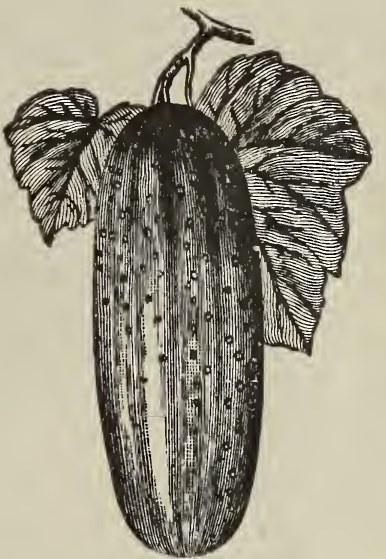

PEERLESS WHITE SPINE.

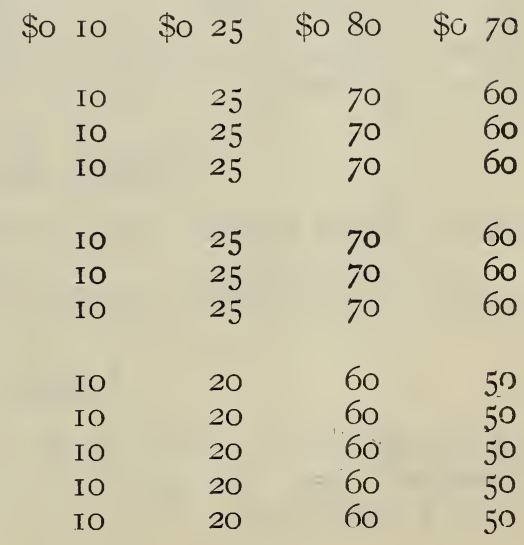




\section{CUCUMBER-continued.}

Extra Early Russian. Small, extra early variety,

Cool and Crisp. Med. length, very dark green, crisp and tender, . . .

Improved Long Green. Extra long, fine quality, for pickles, .

Gherkin or Burr. Small prickly sort, used for small pickles, .

\section{DANDELION.}

Improved French Large-Cut-Leaved.' Excellent for greens, .

\section{EGG PLANT.}

Early Round Purple. Small, early variety, . . . . 25

New York Improved Purple. Old standard, . . . . 30

Improved Spineless. Improvement on the above, no spines, . 35

Black Beauty. Earlier than N. Y. Imp., fine quality, . .

\section{ENDIVE.}

Moss Curled. Very fine curled,

Green Curled. Hardy variety for fall or winter,

White Curled. Very attractive variety, . IO

Broad-Leaved Batavian. Large head of broad, thick leaves, .

\section{HERBS.}

Caraway. Grown for the seeds used in pastry, etc., . . . 5

Coriander. Seeds are used in confectionery, . . . . 5

Dill. Leaves used for flavoring, . . . . . . . 5

Fennel. Leaves used in sauces and for garnishing, . . . 5

Horehound. Used in manufacturing cough medicine, . . I5

Lavender. Sometimes used in making perfumery, . . . I5

Sweet Marjoram. Leaves are used for flavoring and other culinary purposes,

Sage Used extensively for seasoning and $\dot{0} \cdot \dot{0}^{\circ}$ IO

Summer Savory. Useful in culinary purposes,

Thyme. Leaves used for seasoning,.

\section{KALE, or BORECOLE.}

Dwarf Curled Scotch. Hardy, bright green, tender and fine flavor,

Green Curled Scotch. Grows taller than the above,. .

Dwarf Germans. A great favorite with Germans for greens,

Siberian Curled. Very hardy, dwarf greyish green leaves, .

\section{KOHL RABI.}

Early White Vienna. Early and good flavor. Commonly used in this country,

Early Purple Vienna. Similar to the above only in color,

\begin{tabular}{|c|c|c|}
\hline 80 & 300 & \\
\hline I IO & 375 & \\
\hline I 25 & 400 & \\
\hline $\begin{array}{ll}1 & 25\end{array}$ & 400 & \\
\hline
\end{tabular}

$\begin{array}{ll}90 & 80 \\ 90 & 80 \\ 90 & 80 \\ 90 & 80\end{array}$

\section{LEEK.}

American Flag. Large, hardy and productive, 


\section{LETTUCE.}

Early White Seeded Tennis Ball or Boston Market. Early cabbage heading variety; medium size, green leaved. A good variety for forcing,

Early Black Seeded Tennis Ball. Improved strain, black seed, Early Curled White Seeded Simpson. Old popular variety, . Early Curled Black Seeded Simpson. Large, loose head, Market Gardener's Private Stock. Improved Salamander, Deacon or San Francisco Market. Large, solid head, summer variety,

Henderson's New York Head. Solid head, dark green, .

Early Prize Head. Large, loose head, tinged with brown; excellent,

Big Boston. Excellent for forcing or field culture, large solid green heads,

Grand Rapids (black seed). Great for early forcing, . .

Iceberg. Solid head variety, crisp and tender. Good for either early or late planting,

Black Seeded Satisfaction. Resembles Salamander,

Salamander. One of the best summer varieties for standing heat, compact tender head, green crumple leaved, . .

Trianon Cos or Celery Lettuce. Leaves when bleached are stiff. like celery,
Improved Hanson. Old and staid head variety, . •

Per oz

Per $1 / 41 b$.

or more

\$o IO

\$o 20

\$o 70

$\$ 060$

IO

IO

20

20

70

60

60

50

IO

20

70

60

IO

25

80

70

IO

25

80

70

25

80

70

IO

20

70

60

IO

25

80

90

70

25

25

80

80

70

20

70

60

25

80

70

IO

25

80

70

25

80

70

\section{OKRA.}

Dwarf White Velvet. Smooth white velvety pods, .

Improved Dwarf Green. Plants dwarf, good size green pods,

Long Green Pod. Long slender green pods,

\section{WATERMELON.}

Vick's Early. A good small melon, skin varies in color.

Early Fordhook. Short, blocky melon, early, large and of delicious flavor, dark green skin, striped with light green,

Cole's Early. Oblong, striped skin, flesh rich red, fine quality,

Phinney's Early. Fair size, extra early, .

Peerless or Icecream, oblong, white seeded, sweet, . . .

Kleckley Sweet. A good medium early melon, . . .

Kolb Gem. Very large, late melon; excellent shipper, . .

Dark Icing. Dark green skin, solid red flesh, good quality.

Sweet Heart. Large, round, medium early, skin mottled light green, flesh rich red, fine quality,

Improved Mountain Sweet. Old reliable sort, . . . . . 5

Florida Favorite. Large, oblong, med. early, fine flavor, . 5

Cuban Queen. Large, late melon, . . . . . . 5

Colorado Citron. For preserving, green seeded, 


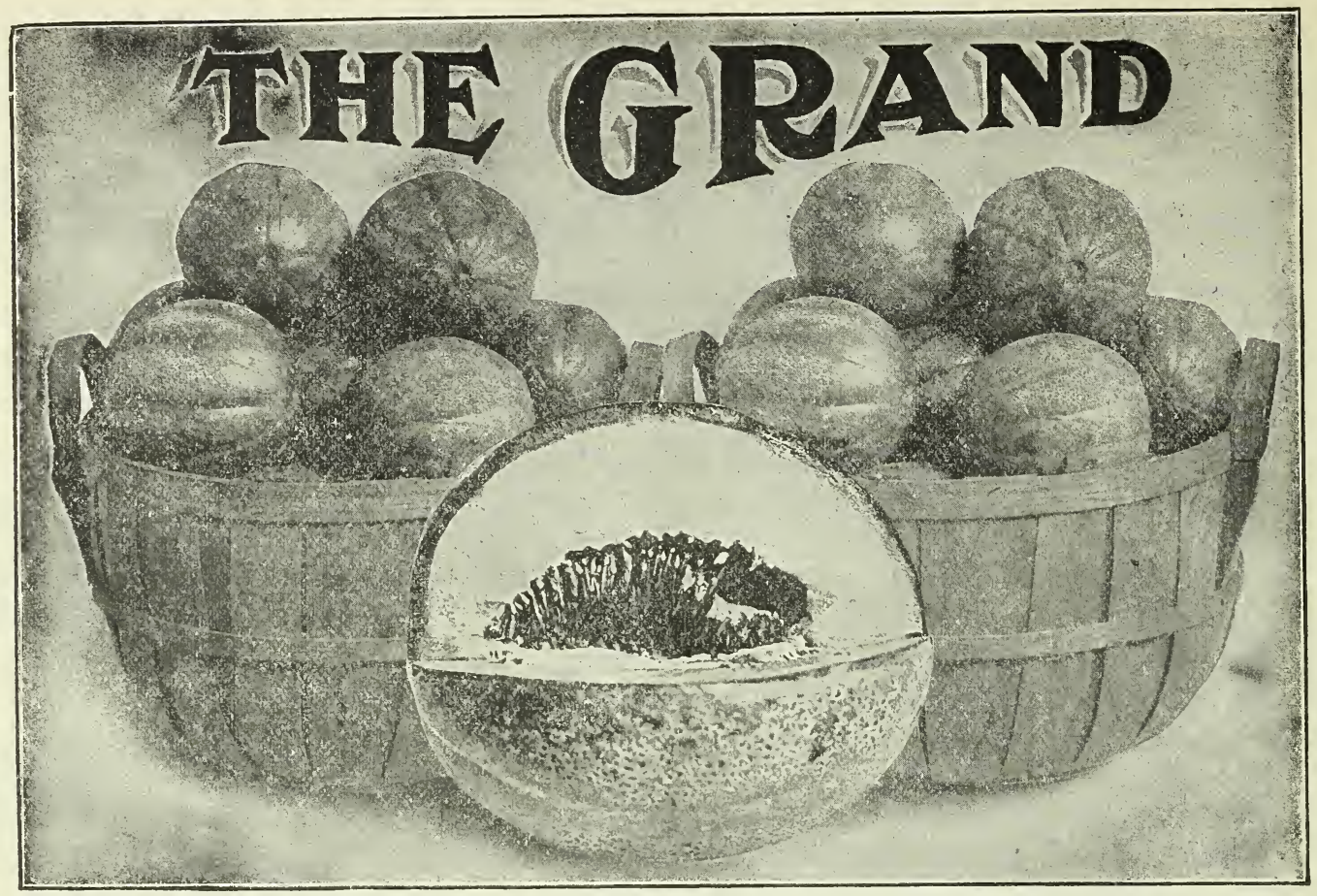

MUSKMELON.

The Grand. A melon that deserves to be planted in every garden. Good size, green skin well netted, flesh salmon color, very thick and superior quality,

Paul Rose or Petoskey. Slightly oval, fine netted, heavy ribbed, yellow flesh and very sweet,

Extra Early Jenny Lind. Extra early; small, green flesh, .

Miller's Cream or Osage. Globe shape, dark green skin; flesh salmon color,

Early Hackensack. Week earlier than late Hackensack,

Montreal Green Nutmeg. Large, green flesh, round with flattened ends,

Hackensack or Turk's Cap. Large, round, green flesh, deeply ribbed,

Improved Christiana or Boston Pet. Extra early, med. size, green skin, rich yellow flesh,

Long Island Beauty. Improved Hackensack, .
Prolific Green Nutmeg. More prolific than Green Nutmeg,

Rocky Ford. Oblong, fair size and finely netted, sweet, green flesh; great shipper,

Emerald Gem. One of the best melons that grows, salmon

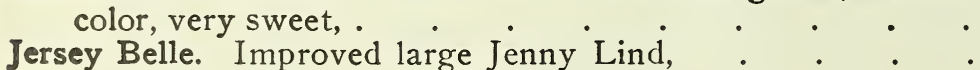

\section{PARSLEY.}

Emerald or Extra Dwarf Curled. Handsome, green curled, Taber's Exquisite Dwarf, Dark Green Curled. A fine variety, Extra Triple Curled. More curled than any other,. . . Double Curled. Old standard, . .
Champion Moss Curled. Improvement on Double Curled.

Per oz. Per $1 / 41 \mathrm{~b}$. Per $1 \mathrm{~b}$.

\begin{tabular}{|c|c|c|c|c|}
\hline IO & 30 & I & O० & \\
\hline IO & 25 & & 75 & \\
\hline IO & 30 & I & $\mathrm{OO}$ & \\
\hline 10 & 30 & I & ०० & \\
\hline IO & 35 & I & 25 & I \\
\hline 10 & 30 & I & ०० & \\
\hline IO & 30 & I & $\mathrm{OO}$ & \\
\hline IO & 30 & I & O० & \\
\hline IO & 30 & I & $\mathrm{OO}$ & \\
\hline IO & 25 & & 75 & \\
\hline 15 & 30 & I & IO & I \\
\hline IO & 25 & I & $\mathrm{OO}$ & \\
\hline
\end{tabular}
Per oz. Per $1 / 4$ lb. Per lb. Per $1 b$.

$\begin{array}{rlll}5 & \text { I } 5 & 50 & 45 \\ 10 & 20 & 60 & 55 \\ 10 & 20 & 60 & 55 \\ 5 & 15 & 50 & 45 \\ 5 & 15 & 50 & 45\end{array}$




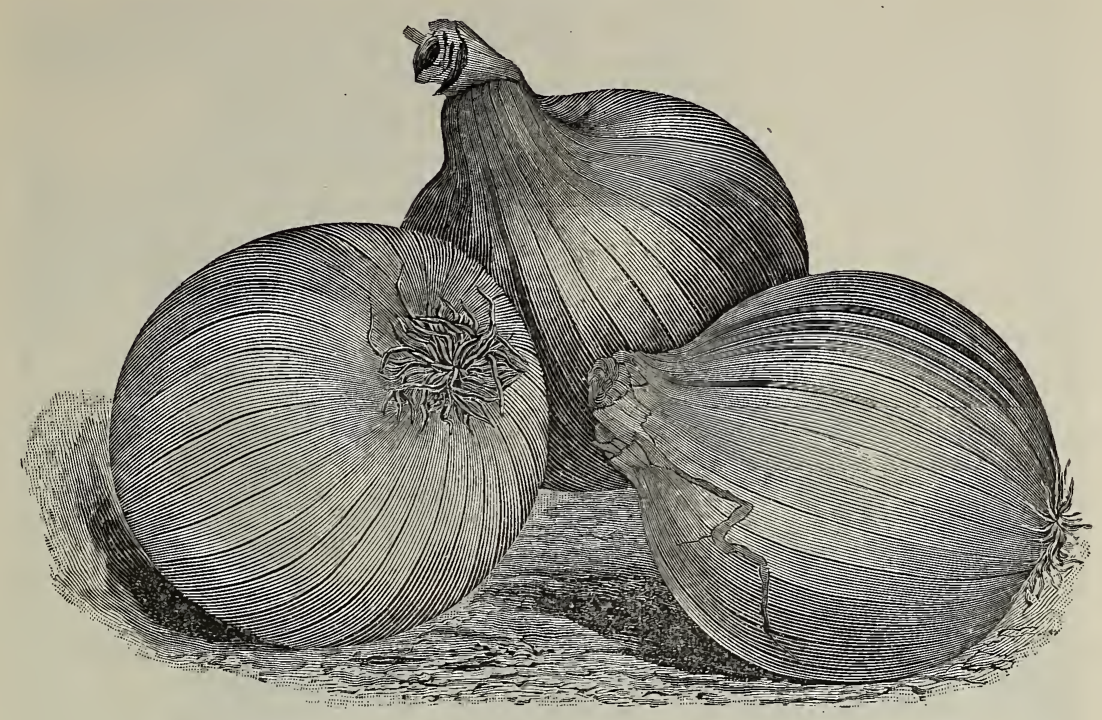

Perfect Yellow Globe Danver's Onion.

\section{ONION.}

Wethersfield (sometimes called Onion town) is noted for its fine quality of onion seed. We are old onion seed growers and are very careful to have our stocks pure and of the best quality, and we sell large quantities every year to a very critical trade.

Yellow Danvers. Round, bright yellow, .

Yellow Globe Danvers. A globe shaped onion, little flattened

at bottom,

Perfect Yellow Globe Danvers. A very fine strain, . $\quad . \quad$ :

Ohio Yellow Globe. Very popular in Ohio markets, . .

Southport Yellow Globe. True globe shaped,
Yellow Dutch or Strasburg. Flat onion, sowed extensively for sets,

Prize Taker. Very large, handsome yellow onion, $\dot{R}$ Early Red Flat. About ten days earlier than
Eld

Large Red Wethersfield. The old reliable,

Southport Red Globe. Great for Eastern markets,

Silver Skin or White Portugal. Flattish round onion, good quality,

Southport White Globe. Best white onion for market,

Early White Barletta. Extra early, small pickling onion,

Early White Queen. Quite similar to Barletta,

\begin{tabular}{|c|c|c|c|c|}
\hline Per oz. & Per $1 / / 1 \mathrm{lb}$. & & $\begin{array}{l}511 \\
\text { or m } \\
\text { Per }\end{array}$ & \\
\hline \$O $\quad$ I 5 & \$o 30 & $\$ 1 \quad 20$ & \$I & IO \\
\hline I 5 & 35 & I 25 & I & I 5 \\
\hline I 5 & 35 & I 35 & I & 25 \\
\hline I5 & 35 & I 25 & I & I 5 \\
\hline I 5 & 35 & I 35 & I & 25 \\
\hline I 5 & 35 & I 25 & I & I 5 \\
\hline I 5 & 35 & I 35 & I & 25 \\
\hline I 5 & 40 & I 40 & I & 30 \\
\hline I 5 & 40 & I 40 & I & 30 \\
\hline I 5 & 35 & I 35 & I & 25 \\
\hline 20 & 65 & 200 & I & 80 \\
\hline 25 & 75 & 250 & 2 & \\
\hline I 5 & 40 & I 40 & I & 30 \\
\hline I 5 & 40 & I 40 & I & 30 \\
\hline
\end{tabular}

\section{ONION SETS.}

Please remember that we give $35 \mathrm{lbs}$. to the bushel. Most dealers only give 32 lbs.

Red Onion Sets, (Bush. 35 lbs.) .

Per quart. 4 quarts.

Per pk.

Per bu.

5 bus.

\$o I 5 \$o 45

\$o 75

$\$ 275$

Per bu.

Yellow Onion Sets (Bush. 35 lbs.) . . . . . . $\quad$ I5 45

White Onion Sets (Bush. 35 lbs.)

20

55 


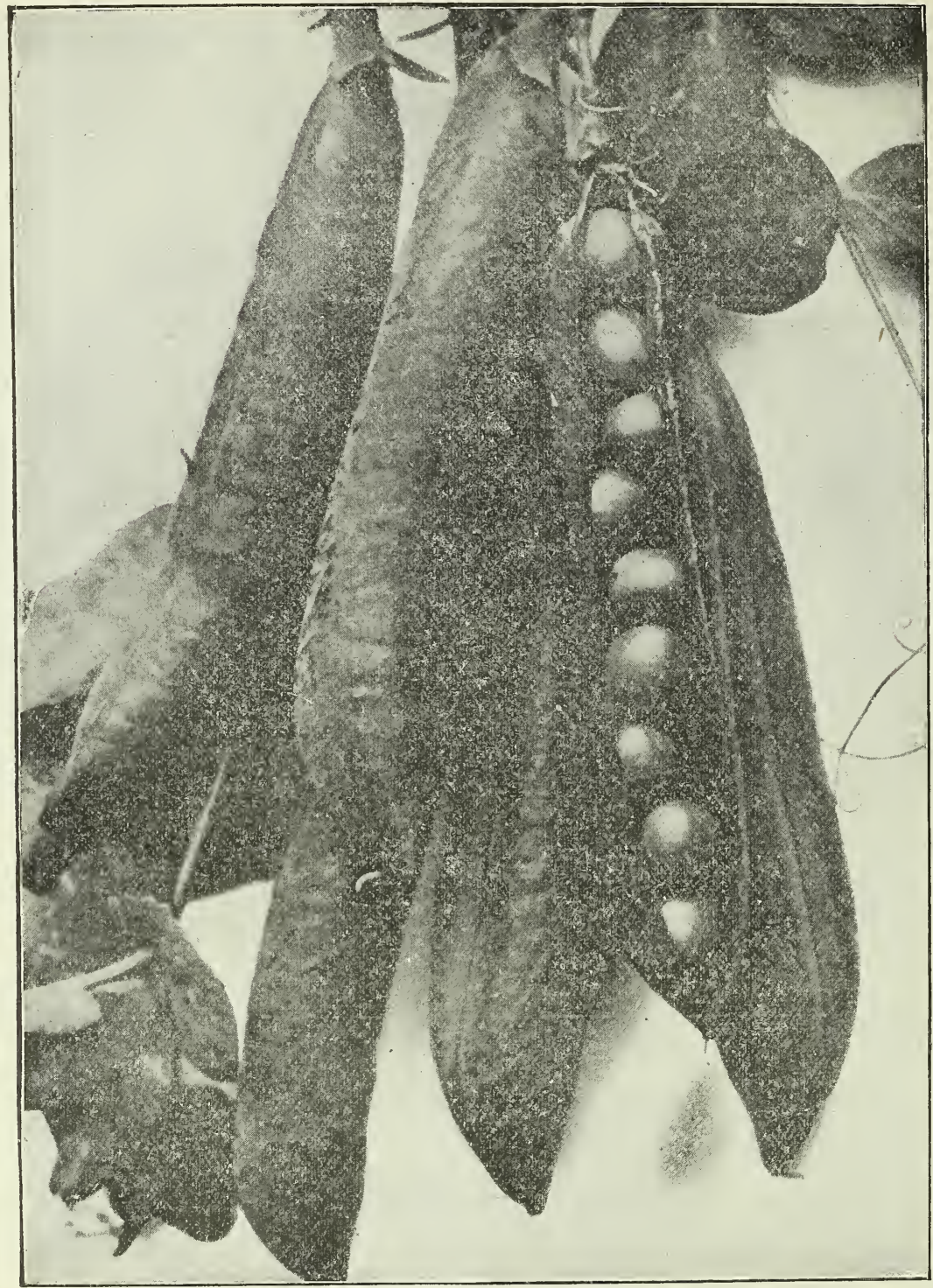

THOMAS LAXTON PEAS.

The shortage in the Pea crops has made Peas very scarce this season but we hope to be able to take care of our customers.

\section{PEAS.-First Early Varieties.}

Maud S. Superior strain of the extra early variety, $2 \frac{1}{2}$ feet, . East Hartford Extra Early. Very popular with gardeners around Hartford, $21 / 2$ feet,

Philadelphia Extra Early. The old and tried sort, $2 \frac{1}{2} / 2$ feet, First and Best. One of the earliest, $2^{1} / 2$ feet, . . . . Alaska or Laxton's Earliest of All. Good market variety, 21/2 feet,

*Gradus or Prosperity. Earliest large podded variety, extra fine; our strain is of true type, $2^{1 / 2}$ to 3 feet,

* Thomas Laxton. Large handsome pods, first class quality, 3 feet,

*Extra Early Premium Gem. Imp'd Little Gem, I5 inches,

\begin{tabular}{|c|c|c|c|}
\hline $\begin{array}{l}\text { Per quart } \\
\$ 020\end{array}$ & $\begin{array}{l}4 \text { quarts } \\
\$ 075\end{array}$ & $\begin{array}{l}\text { Per peck. } \\
\$ 140\end{array}$ & $\begin{array}{l}\text { Perbu. } \\
\$ 5 \quad 25\end{array}$ \\
\hline 20 & 75 & I 40 & 525 \\
\hline 20 & 75 & I 35 & 500 \\
\hline 20 & 75 & I 35 & 500 \\
\hline 20 & 75 & I 40 & 525 \\
\hline 30 & I IO & 200 & 750 \\
\hline 25 & 90 & I 60 & 600 \\
\hline 20 & 75 & I 35 & 525 \\
\hline
\end{tabular}


First Early Varieties.-Continued.

*McLean's Little Gem. A very popular garden pea, I8 inches,

*American Wonder. Medium sized pod, flavor of the best, 9 inches,

*Nott's Excelsior. Improved American Wonder, better yielder, I 5 inches,

*Sutton's Excelsior. This is one of the best peas in cultivation, similar in growth to Nott's Excelsior, but excelling same in bearing; much larger pods filled with large tender peas of delicious flavor, I5 inches,

\section{Second Early Varieties.}

*Bliss' Abundance. Well filled pods, prolific, fine flavor, 20 in.,

*McLean's Advancer. Good sized, well filled pods, excellent quality, 2 feet,

*Shropshire Hero. Much improved Yorkshire Hero, better quality, $2 \frac{1}{2}$ feet, .

*Horsford Market Garden. Similar to Abundance, 2 feet, .

*Heroine. Pods long, filled with fine flavored peas, very prolific, 2 feet,

*Juno. Robust and vigorous in growth bearing straight pods of medium size, and well filled with fine flavored peas, $2 \mathrm{ft}$.,

\section{General Crop Varieties.}

*Sharp's Queen. Large, handsome pods; delicious peas, $21 / 2 \mathrm{ft}$. *Improved Stratagem. Valuable market garden sort, 2 feet,

*Bliss' Everbearing. Vigorous branching vines, good sized pods, 2 feet, .

*Dwarf Champion or Duke of Albany. Fine variety, $2 \mathrm{t} / 2 \mathrm{ft}$.,

Boston Unrivaled. This variety takes the place of Carter's Telephone, and while it is quite similar to Telephone in most respects, it is of much purer type. Vigorous vine, long, straight, broad pods, well filled with large peas of excellent quality, 3 to 4 feet,

*Allan's Improved Telephone. A much improved type of Carter's Telephone, longer and deeper green pods, $3^{\mathrm{T}} / 2$ feet,

*Sutton's Defiance. Large pods full of delicious flavored peas, 20 inches,

*Admiral Dewey. Remarkably healthy, vigorous and very productive. Pods of large size, straight, rounded at point, dark green color and filled with large, rich flavored peas, 4 feet,

*Champion of England. Everybody knows this variety, 5 feet,

Black Eyed Marrowfat. More for stock feeding,

Canada Field. Excellent to sow with oats for feed, *Wrinkled Varieties.

\section{PARSNIP.}

Improved Guernsey. Med. long, superior quality,

Hollow Crown Improved. One of the best for general use, . Large Smooth Sugar. Quite like Hollow Crown,

\section{PEPPER.}

Neapolitan. A large, early, bright red Pepper of mild flavor. Shape similar to Sweet Mountain. Heavy producer,

Large Bell or Bull Nose. A thick pepper, excellent for stuffing,

Sweet Mountain. Little longer shaped than Bull Nose,

Ruby King. Very large and mild flavcr.

Ruby Giant. A cross between Ruby King and Chinese Giant, resembling Ruby King but much larger fruit and more prolific,
Per quart.

$\$ 020$

25

25

So 75 \$ 35

Per bu.

80

I 55

610

I 55

6 io

25

85 I 60

625

20

20

20

20

20

20

75

I 35

500

75

I 35

500

75

I 35

75

I 35

500

500

75 I 35

500

75

I 35

500

20

25

20

20

75

I 35

500

80 I 45

550

75 I 35

500

$\begin{array}{lll}65 & \text { I } & 25\end{array}$

450 




MAINE GROWN SEED POTATOES.

Maine grown Seed Potatoes still remain at the head for seed stocks to grow from. It's wonderful how universally popular these potatoes have become and how many thousands of bushels are planted annually. Practically every planter in this section plants this northern grown seed in preference to his own stocks and he is no doubt wise in doing so as better results follow. We made unusually heavy contracts for these potatoes for our spring trade and have them stored in Maine in frost proof cellars to be shipped to us in the Spring and expect them to arrive about April Ioth, when they can be re-shipped direct to our customers or notice sent to parties who wish to call for them.

As we have placed heavy contracts we quote very favorable prices but reserve right to change prices should we deem it advisable or necessary.

Junior Pride or White Bliss. Resembles Irish Cobbler in sacks or more of Per bbl. same variety color and shape but far superior in quality. Early, round, uniform in shape, very productive and good keeper. Try this variety, it will please you,

Irish Cobbler. Early, cream-white color, nearly round; fair quality; vigorous grower,

Early Harvest. Handsome oblong white potato; great yielder, Early Rose. An old well-known variety,

Early Beauty of Hebron. A great favorite with most planters, Carman No. I. Heavy yielder of large handsome white potatoes; fine quality,

Carman No. 3. Longer in shape than No. I, excellent quality,

Golden Prolific. We planted several sacks of this variety this past season and they proved to be very productive of large, handsome, whitish potatoes and of exceedingly fine quality. Medium early and good keeper, and we highly recommend this variety for general crop, 


\section{SEED POTATOES. - Continued.} Per bbl. Per sack. Sack 165 lbs. net.

Green Mountain. Large, white, handsome potato; very popular,

Delaware. Resembles Green Mountain, medium early, late keeper, great cropper,

\section{$\$ 300 \quad \$ 280$ \\ 3 I0 290}

\section{PUMPKIN.}

Winter Luxury. An excellent small pie pumpkin, round, golden russet color, finely netted, flesh yellow, sweet and tender, good keeper,

Small Yellow Sugar. One of the best pie pumpkins,

Large Cheese. Round, flattish pumpkin, ribbed,

Mammoth Tours. Very large, green color,

Mammoth Potiron or King of Mammoth. Great pumpkin for fairs,

Connecticut Field. Old standard, excellent for feeding,

Per o

Per $1 / 4 \mathrm{lb}$

5 lbs.

or more
Per $1 \mathrm{~b}$.

\begin{tabular}{|c|c|c|c|c|}
\hline 010 & \$o 20 & \$o & 50 & \$o \\
\hline 5 & I 5 & & 35 & \\
\hline 5 & 15 & & 35 & \\
\hline IO & 30 & I & Do & \\
\hline IO & 30 & 1 & po & \\
\hline 5 & 10 & & 20 & \\
\hline
\end{tabular}

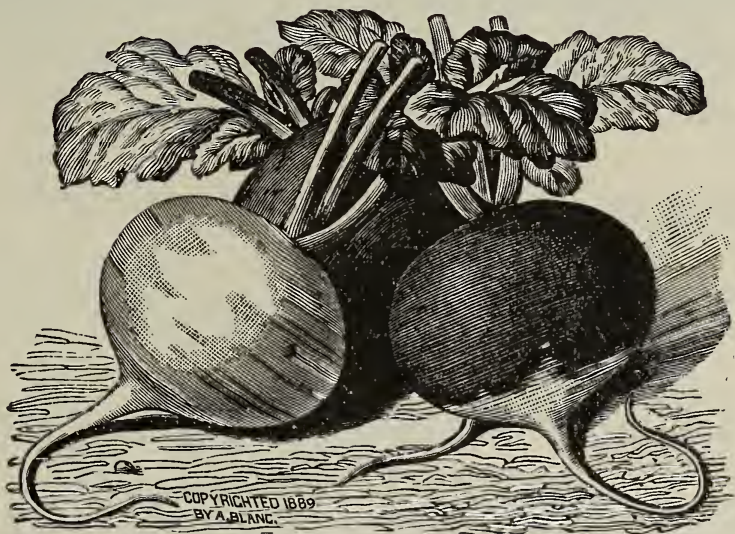

RADISH.

The Sparkler. This is a new, bright red radish with white tip. Extra early, tender and crisp, . $\quad$ I 5

Carmine Olive-Shaped. A beautiful bright red radish, . . IO

Extra Early Erfurt. One of the earliest turnip radishes, . 10

Rosy Gem. Either for greenhouse or open culture; round white tipped,

Early Scarlet Globe. One of the best market varieties,

Early Deep Scarlet Turnip. Very deep color ; excellent, . 5

Half Long Deep Scarlet. Excellent, of medium length, . 5

Early Red Turnip. A popular garden variety, . . . . . 5

Early Scarlet Turnip. Like the preceding, lighter color, . 5

Early Scarlet Turnip, White Tip. Round scarlet radish with white root,

Early French Breakfast. A short radish with white root,

Early White Turnip. An early summer variety, . ${ }_{\text {Olive Shaped Scarlet. Shaped like an olive, bright scarlet color, }}$ Early Short Top Long Scarlet. The old standard long radish, 


\section{RADISH.-Continued.}

White Strasburg. A leading summer variety,

White Vienna or Lady Finger. Long, slim radish,

Chartier. A long scarlet radish, white root,

Chinese Rose-Winter. Excellent winter variety,

Long Black Spanish-Winter. Large and hardy, keeping until spring,

Round Black Spanish-Winter. Globe-shaped, fine quality, .
Peroz. Per $1 / 4 \mathrm{lb}$. Per $\mathrm{lb}$

\begin{tabular}{|c|c|c|c|}
\hline \$o 05 & \$o & I 5 & So \\
\hline 5 & & 15 & \\
\hline 5 & & 15 & \\
\hline 5 & & I 5 & \\
\hline 5 & & I 5 & \\
\hline 5 & & I 5 & \\
\hline
\end{tabular}

$51 \mathrm{lbs}$.

or more

\$o 35

35

35

35

35

35

\section{RHUBARB, or Pie Plant.}

Large Victoria. The most popular variety,

\section{SUNFLOWER.}

Mammoth Russian. Very large flower, seeds excellent for fowls,

\section{SALSIFY, or Vegetable Oyster.}

Long White. The standard variety,

Mammoth Sandwich Island. The largest,

\section{SPINACH.}

Early Giant Thick-Leaved. A fine early spinach,

Curly Savoy or Bloomsdale. Good variety to sow in fall for spring use,

Round Summer. The old round-leaf sort,

Long Standing. Said to stand two weeks longer than other varieties,

Victoria. One of the best round spinaches, $. \quad \cdot \quad . \quad$.

Large Viroflay Thick-Leaved. Popular with market gardeners,

\section{SQUASH.}

Early White Bush Scallop. A flat scalloped variety, . . IO

Early Golden Bush Scallop. Like the above only in color, .

Early Summer Crookneck. Best early table squash, . .

Giant Summer Crookneck. Larger than the preceding, : .

Early Orange Marrow. Med. size, excellent for fall or winter,

Dunlap's Prolific Marrow. Quite similar to the above, .

The Delicious. Shaped similar to the Hubbard, color of skin varying from light green to dark green. Fine grained orange colored flesh, good flavor,

Boston Marrow. A good keeper of fine quality; yellow skin, .

Essex Hybrid. Creamy-orange, round, flattened ends, nub at flower end,

Improved Hubbard.. Old standard improved, . $\cdot$. $^{\circ}$ :

Chicago Warted Hubbard. Fine quality,
Golden Hubbard. Like Improved Hubbard only in color, . 


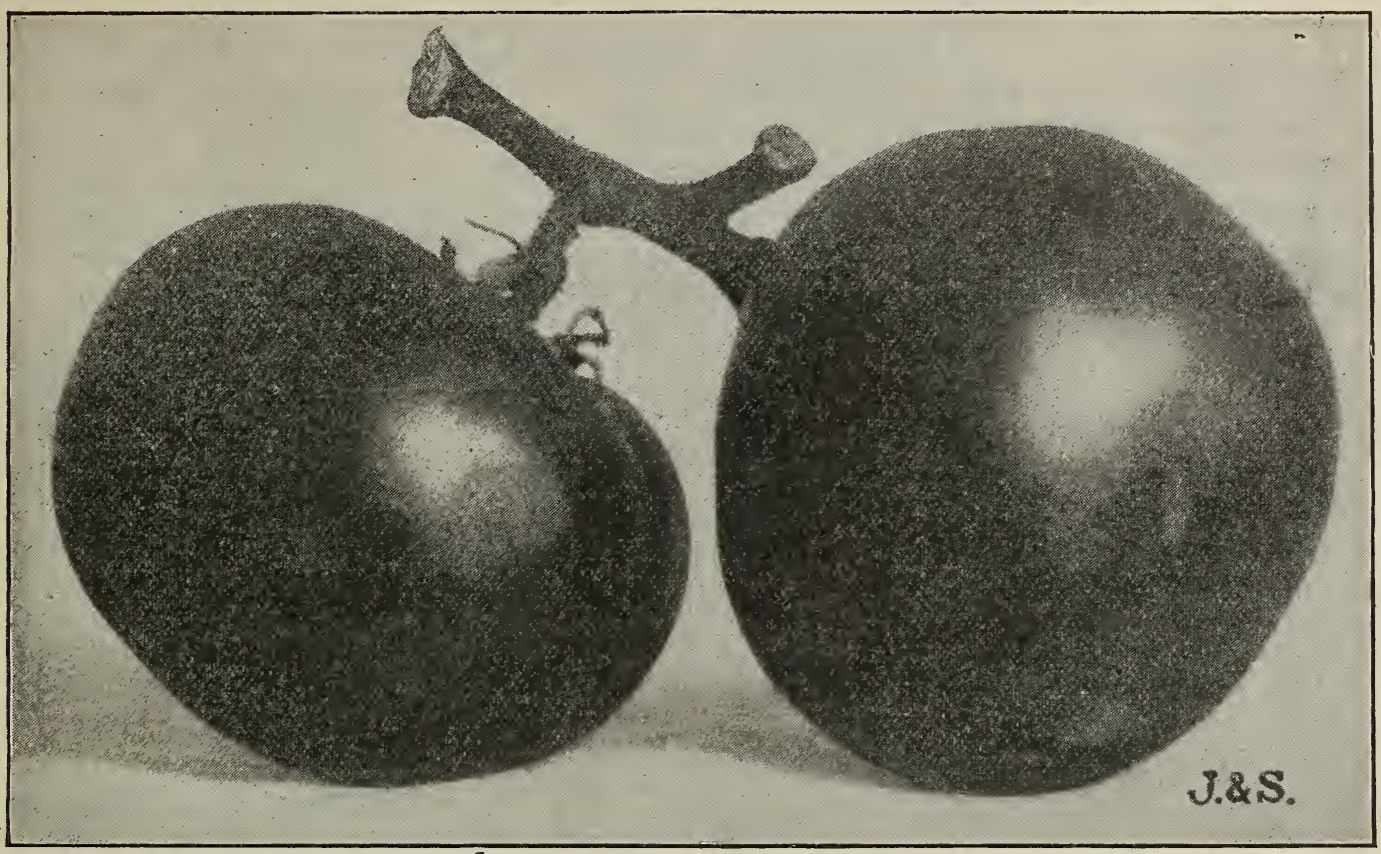

\section{TOMATO.}

June Pink. Early pink tomato of good quality,

Chalk's Early Jewel. Best extra early, smooth, red tomato, .

Sparks' Earliana. Very early, good size, but inclined to be rough,

Atlantic Prize. A fine, extra early, red variety for general use, Early Acme. Food family tomato; solid, pinkish color,

Iivingston's Pink Globe. A very good all-round Tomato, but if grown on very rich soil is liable to crack. Pink in color, globe shaped, flesh very meaty, good flavor and great cropper, 20

Livingston's Coreless. One of Livingston's new productions, a large, bright red Tomato, globe shaped, strong grower

Livingston's Beauty. Large, thick tomato, light purple, .

Livingston's Favorite. Bright red and smooth,
Livingston's New Stone. The best all around tomato, bright red,

Livingston's Prefection. A favorite with canners, . .

Livingston's New Dwarf Stone. Short, stocky vine; fine large, smooth, red tomato,

Large Red Trophy. Old standard, . . . . . .

Golden Trophy. Like the preceding, only yellow, . . .

Golden Queen. Similar to Golden Trophy,

\begin{tabular}{|c|c|c|c|}
\hline Per oz & Per $1 / 4 \mathrm{lb}$. & Per 1h. & $\begin{array}{l}51 \mathrm{bs} . \\
\text { or more } \\
\text { Per } 1 \mathrm{~b}\end{array}$ \\
\hline 20 & So 65 & $\$ 250$ & $\$ 225$ \\
\hline 20 & 65 & 250 & \\
\hline 20 & 65 & 250 & \\
\hline I 5 & 45 & I 60 & I \\
\hline 15 & 45 & I 60 & I \\
\hline
\end{tabular}

Dwarf Champion. Solid, smooth dwarf, pinkish variety,

Dwarf Aristocrat. Like Dwarf Champion, bright red,

Table Queen. Purplish red, large and solid, 


\section{TURNIP.}

Extra Early Milan Purple-Top. The earliest,

Purple Top Flat Strap-Leaved. Well-known variety, •

Early White Flat Dutch. Same shape as the preceding, white

Large Red Top Globe. Large white turnip with red top,

Long White Cow Horn. Heavy cropper; excellent for stock,

White Egg. Handsome pure white, med. size; fine market variety,

Pomeranian White Globe. Large, pure white,

Yellow Aberdeen. Very large green top, good for table or stock

Yellow Stone. Very solid and smooth; excellent for winter, .

Golden Ball. A smallish, smooth, yellow turnip; excellent keeper,

Purple Top Yellow Globe. Large yellow turnip with purple top,

Green Top Yellow Globe. Old standard variety,

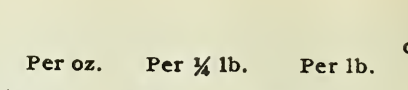

\$o 05 \$o I5 \$o 40 \$o 35

5 10 $25 \quad 22$

5 10 $25 \quad 22$

5 10 $25 \quad 22$

$5 \quad 10 \quad 25 \quad 22$

$5 \quad 15 \quad 30 \quad 25$

$5 \quad 15 \quad 30 \quad 25$

5 10 $\quad 25 \quad 22$

$5 \quad$ I0 $\quad 25 \quad 22$

$5 \quad 10 \quad 25 \quad 22$

$5 \quad$ 10 $\quad 25 \quad 22$

$5 \quad 10 \quad 25 \quad 22$

5 I0 25

\section{RUTA BAGA, or Swedish Turnip.}

Sweet German. Long, white, smooth and tender, White French or Rock. Improvement on the preceding, . Breadstone or Budlong. The best white variety, . . . Am. Improved Purple-Top Yellow. Very hardy and productive,

Skirving's Purple-Top Yellow. Large size, strong growth, . Waite's Improved Purple-Top Yellow. An improved type, Long Island Improved Purple-Top Yellow. One of the best, .

$\begin{array}{llll}5 & \text { 10 } & 25 & 22 \\ 5 & \text { 10 } & 25 & 22 \\ 5 & 10 & 25 & 22 \\ 5 & & & \\ 5 & 10 & 25 & 22 \\ 5 & \text { 10 } & 25 & 22 \\ 5 & \text { 10 } & 25 & 22 \\ & 10 & 25 & 22\end{array}$

We furnish seed to Granges, Farmers' Clubs, Public and Private Institutions and thousands of individuals.

Let us supply your wants in this line. 


\section{GRASS SEED.}

\section{We are Headquarters for High Grade Grass Seed. Don't buy a Poor Grade. The Best is far the Cheapest in the end.}

We aim to handle the very best grades possible. It may cost a few cents more to seed down your land with high grade seed but isn't it a good investment? You are pretty sure to get good results.

We sell tons and tons of high grade seed, and our trade is rapidly increasing. This is the seed you should buy. Prices subject to market fluctuation.

Fancy Lawn Grass Mixture,

Red Top. Sown alone or with Timothy makes excellent hay, Timothy or Herds Grass. Makes fine horse hay (bush. 45 lbs.), Orchard Grass. Good to sow with other grass seed for pasture and shady places, .

Kentucky Blue Grass. Valuable for pasture when mixed with other varieties,

English Rye Grass. A permanent nutritious meadow grass, .

Meadow Fox Tail Grass. Earlier than timothy, which it resembles,

Tall Meadow Oat Grass. Early, luxuriant growth, excellent for pasturing or hay,
Per $1 \mathrm{~b}$.

\$o 20

I9

08

I4

20

I 2

28

2 I or more $251 \mathrm{bs}$. $\quad$ roo $1 \mathrm{~b}$. Per lb Per lb. ormore

\$o 18 \$o 17 \$o 16

IS

O7

I3

I9

I I

27

20

$171 / 2$
$06 \pm \frac{1}{2}$

I5
$06 \mathrm{I} / 4$

I 2

I 2

18

$181 / 2$

09

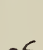

26

I9

18

\section{CLOVER SEED.}

Alsike. Excellent for permanent pasturage, very hardy, good for wet or dry soil (Bush. 6o lbs.),

Alfalfa or Lucerne. IVhen well rooted is very hardy, three crops in one season, fine cow feed (Bush. $60 \mathrm{lbs}$.), . .

White Dutch. Good for pastures, when sown with red clover,

Medium Red. This is the common hay clover so extensively used (Bush. 6o lbs.),

Mammoth Red or Pea Vine. Excellent to plow under for green

manure (Bush. $60 \mathrm{lbs}$ ), Excellent for bees also to plow
Crimson or Scarlet Italian. under (Bush. 60 lbs.),

$\begin{array}{llll}20 & \text { I9 } & \text { I } 81 / 2 & \text { I6 } \\ 20 & \text { I9 } & \text { I8I/2 } & \text { I8 } \\ 24 & 23 & 22 \mathrm{I} / 2 & 22 \\ 20 & \text { I9 } & \text { I8 } & \text { I7 } 1 / 2 \\ 20 & \text { I9 } & \text { I8 } & \text { I7 } 1 / 2 \\ \text { I6 } & \text { I5 } & \text { I4 } 4 / 2 & \text { I4 }\end{array}$

\section{MILLET.}

German or Golden. (Bush. 50 lbs.), slower grower and some taller than Hungarian, .

Hungarian Grass or Millet. (Bush. 48 lbs.), extensively sown to help out late feed and hay crop,

Japanese or Barnyard Millet. (Bush. 32 lbs.), a great forage 


\section{Field and Ensilage Corn.}

Increase your acreage for Field and Ensilage Corn and save large grain bills. The high prices for grains the past few years makes the Eastern farmer realize that he must grow more grain for his own consumption as the West is not likely to be able to supply the East as liberally in the future as in the past. There are thousands of acres of practically waste land here in New England that might be planted to corn and net the owner a neat sum. Last year we sold more corn than ever before and we look for large increase in sales this season.

\section{THOROUGHBRED LEAMING}

We read and hear a great deal about the superiority of this and that variety of Corn, but as far as our observations go we know of no variety ahead of this Improved type of Leaming for Ensilage purposes and we also recommend it for general crop except in northern sections where season is short.

It is a much improved strain of Leaming, ripening about the same time as the old style. Kernels and ears more uniform, better filled out and of much purer type. Stalks are good size with abundance of leaves, and a heavy yielder of large handsome ears. \$o.30 per 4 qts. \$0.50 per peck. \$I.60 per bushel. $\$$ I.5O per bushel for 2 bushels or more.

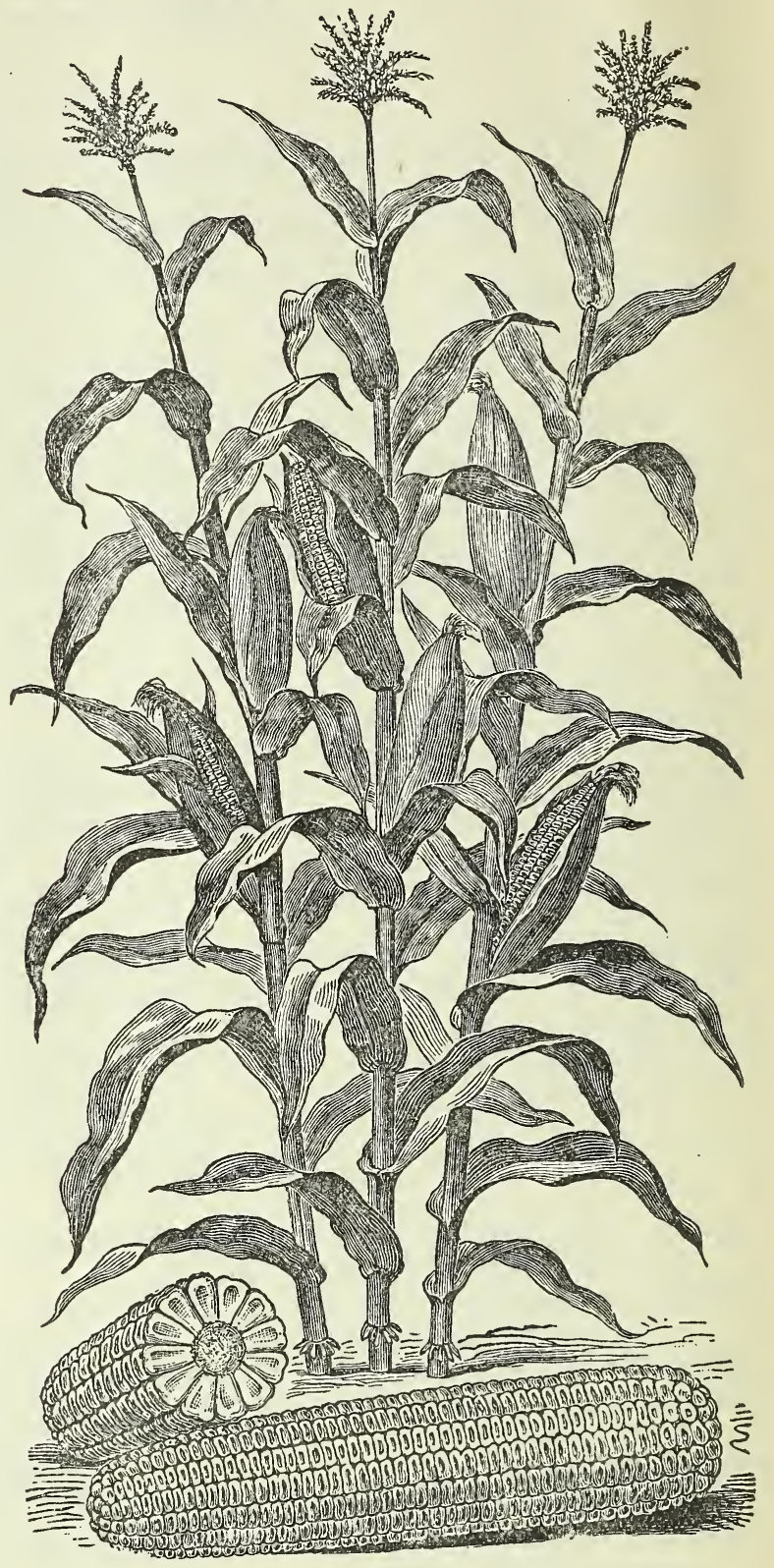

Thoroughbred Leaming

Per 4quarts. Per peck Per bu. $\begin{gathered}2 \text { bus. } \\ \text { or more } \\ \text { Per bu. }\end{gathered}$

Ninety-Day Yellow (true stock); probably the earliest field corn in cultivation; bright yellow flint, small cob and very prolific. A bushel of ears generally shelling about 24 quarts of shelled corn, .

Early Canada Yellow. Medium size flint corn, extensively grown in New England.

\$O 25 \$O $45 \quad$ \$I 50 \$I 35

$25 \quad 45 \quad$ I 50 I 35 


\section{FIELD AND ENSILAGE CORN.-Continued}

Pride of the North. Early maturing Dent variety, good for

ear or ensilage, . Reed's Improved Yellow Dent. A very choice strain of Yellow
. Dent,

Early Leaming. Ears large, deep kernel, excellent for ear corn or ensilage,

Red Cob Ensilage. A late white corn, red cob, used extensively for ensilage,

Sweet Corn for Fodder,

\section{SEED OATS.}

Swedish Select. A variety of Swedish origin brought to this country by the U. S. Department of Agriculture and has proved to be one of the heaviest grain, thinest hull, stiffest straw and heaviest yielding varieties known, . .

Large Dutch. A very heavy, full meated oat quite similar to the Swedish Select,

Lincoln. Early, rust proof and hardy, straw stiff and strong,

American Banner. A thrifty variety well known in New England,

White Queen. An excellent white variety, hardy and prolific,

Silver Mine. Large white oat and very heavy yielder,

So 25

er 4 quarts. Per peck. Per bu.

Per bu.

Common Seed Oats,

\begin{tabular}{|c|c|}
\hline 45 & I 60 \\
\hline 45 & I 50 \\
\hline $\begin{array}{l}45 \\
60\end{array}$ & $\begin{array}{ll}1 & 50 \\
2 & 00\end{array}$ \\
\hline
\end{tabular}

\$I 35

50

35

75

\section{MISCELLANEOUS.}

Russian Sand or Hairy Vetches. (Bush. $60 \mathrm{lbs}$.), sown alone or with rye and clover, makes fine winter covering; excellent to plow under to enrich the soil,

Dwarf Essex Rape. (Bush. 6o lbs.), great for sheep pasture, also for cattle and hogs,

Whip-Poor-Will Cow Peas. (Bush. 60 lbs.), early-maturing variety; vigorous, upright growth,

Clay Cow Peas. (Bush.6o lbs.), well adapted for the north; very productive, $\cdot{ }^{\circ} \cdot{ }^{\circ} \cdot{ }^{\circ}$

Mixed Cow Peas. (Bush. 60 lbs.), different varieties mixed, great for soil enriching,

Spring Rye. (Bush. 56 lbs.), excellent to sow for catch crop where winter crop has failed, or for early feed,

Winter White liye. (Bush. 56 lbs.), a variety for fall sowing to stand over winter,

Best Two-Rowed Barley. (Bush 48 lbs.), sown extensively in New England for fodder, 


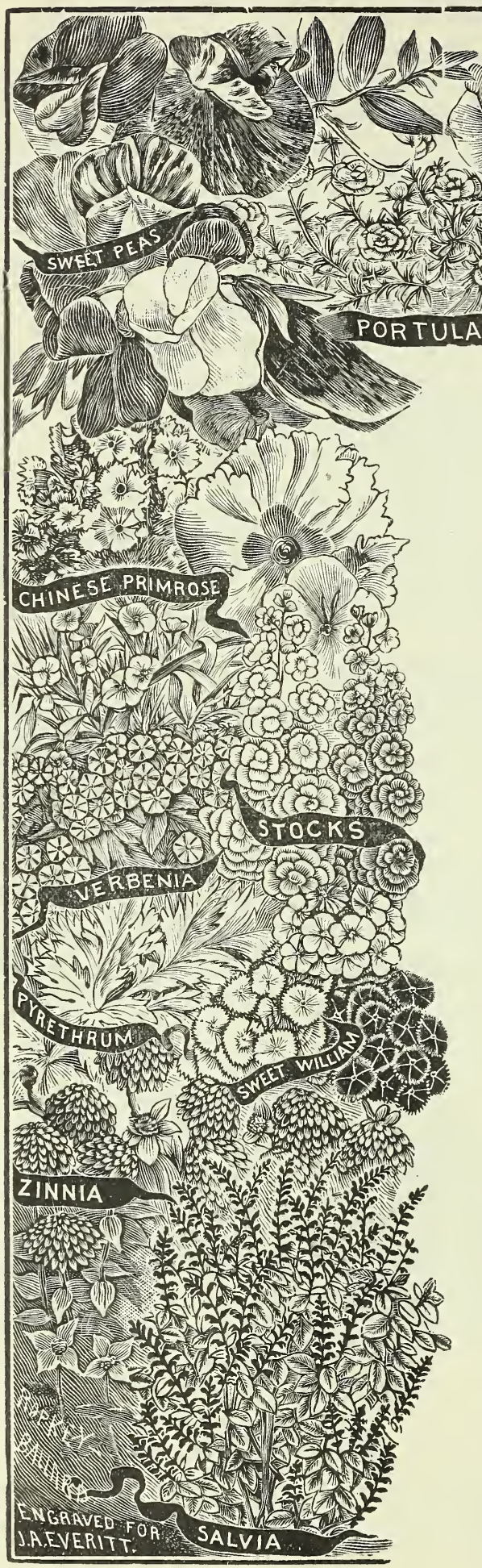

\section{Flower Seeds}

On the following pages we list selections of choice Flower Seeds put up in very liberal packets.

\section{*}

Annuals-Bloom first year from seed and plant dies after one season.

Biennials-Bloom second year from seed and plant dies after second year.

Perennials-Bloom second year from seed and plant lives and blooms for several years.

Tender-Means plant will not stand the least frost.

Half-Hardy-Means plant will stand a little frost and needs protection.

Hardy-Means plant will stand considerable frost. 
AGERATUM (Floss Flower.)

A hardy annual of easy culture. Especially valuable for bedding as it is literally covered with blossoms all summer. Sow the seed early in spring, either in boxes to transplant, or out of doors and thin to four or six inches.

Best mixed varieties, .

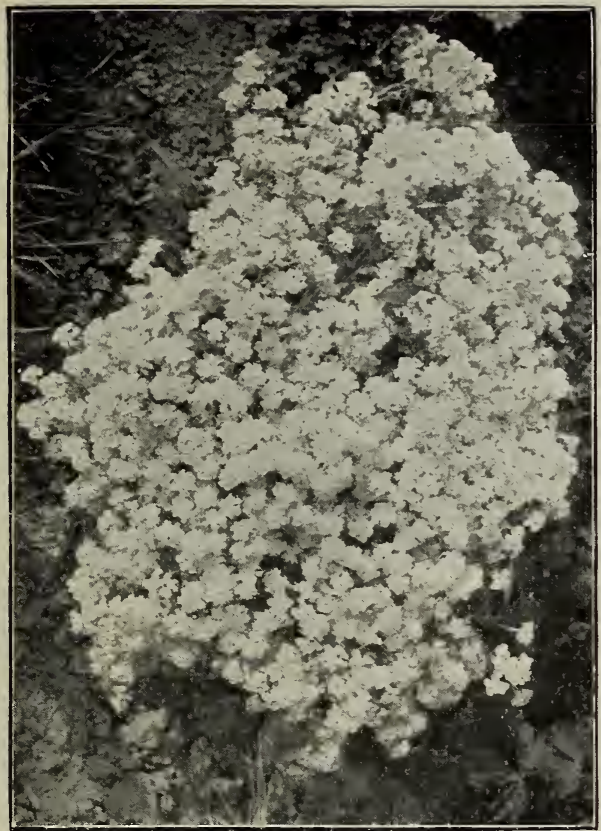

ALYSSUM

ALYSSUM, Sweet.

A fragrant hardy annual, bearing spikes of small, white flowers in great profusion throughout the summer and autumn. Useful for borders or early bedding. Sow the seed early in spring. Per ounce, 20 cts.

White Carpet, Per ounce, 25 cts.

\section{ANTIRRHINUM (Snap Dragon.)}

A half-hardy perennial, growing from 6 inches to 2 feet tall. Flowers are oddly shaped and apparently closed, but by pressing the sides together can be made to open like a dog's mouth.

Extra Choice Mixed,

Per ounce, 25 cts.

\section{ASTERS.}

A popular half-hardy annual, growing from one to two feet high. The best method of culture is to sow the seed in boxes in late winter and transplant about May 1st. The seed can be sown, however, in rows where the plants are to remain, thinning them 10 to 12 inches apart.

Queen of Spring, (white),

Queen of Market, finest mixture, . $\quad .10$

Choice Tall Mixed, best varieties, . . . .10

Best Dwarf Mixed,
Pkt. .05

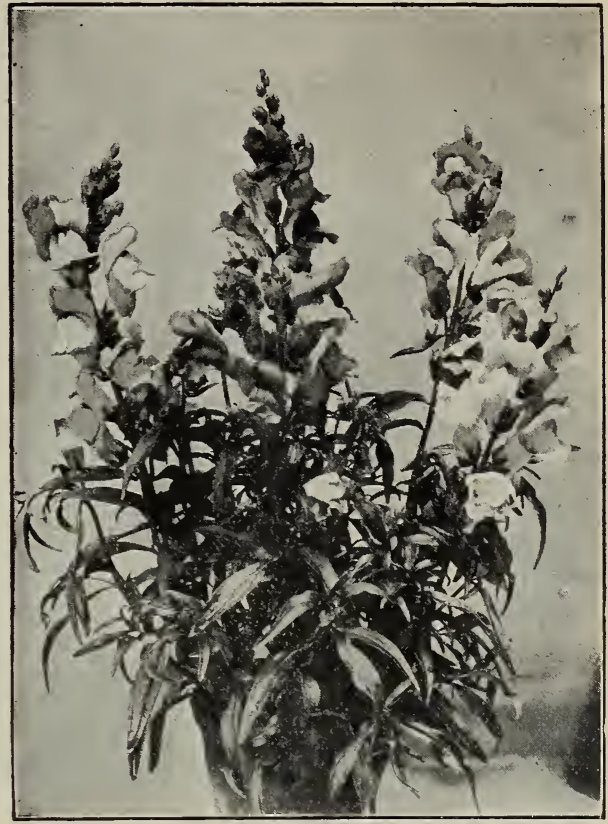

AN'TIRRHINUM

BACHELOR'S BUTTON.

A hardy annual of easy culture. Sow the seed early in spring where it is to remain and thin to 3 or 4 inches.

Finest Mixed Varieties,

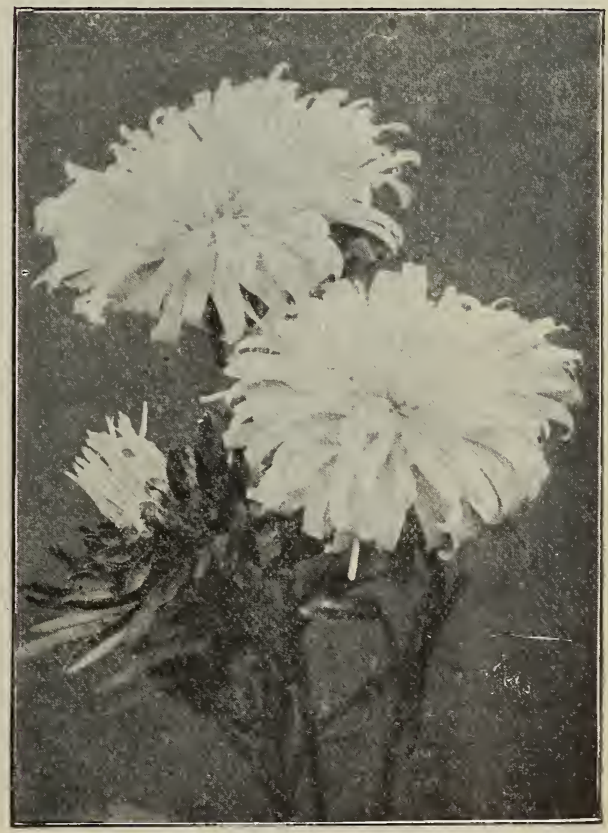

ASTER 


\section{BALSAM OR LADY SLIPPER.}

A tender annual with brittle stem, and foliage, grows about 12 inches high. Flowers are wax-like and very attractive.

Best Double Mixed,

\section{CALLIOPSIS.}

A half-hardy annual, growing 3 feet high and valuable for bright bedding effect or for cut flowers.

Grandiflora,

\section{CANDYTUFT.}

A hardy annual of easy culture, growing 10 to 18 inches high. The flowers are white and borne on various long spikes, forming very large heads, and are used for bedding or cut flowers.

Giant Hyacinth Flowered,

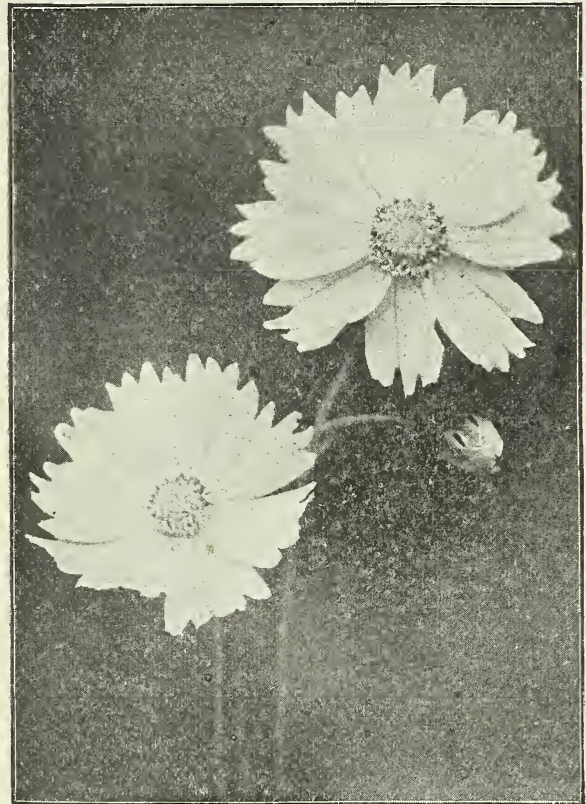

\section{CALLIOPSIS}

\section{CARNATION.}

A half-hardy perennial, used generally for greenhouse trade in winter and for a general garden favorite in summer. Sow the seed early in the year in hotbed and transplant about April 15th.

Margarita Choicest Mixed,

\section{CENTAUREA.}

A hardy annual, growing $11 / 2$ to 2 feet high, bearing beautiful large flowers resembling sweet Sultan, but with a large petal margin around the blossom, sow seed early and transplant.

Imperialis Choice Mixed, .

(See page 30 )
Pkt .05

\section{CLARKIA.}

Hardy annual of easy culture about 18 inches high, flowering in great profusiun, seed sown in fall will give blossoms in spring, and can be sown most any time.

Finest Mixed

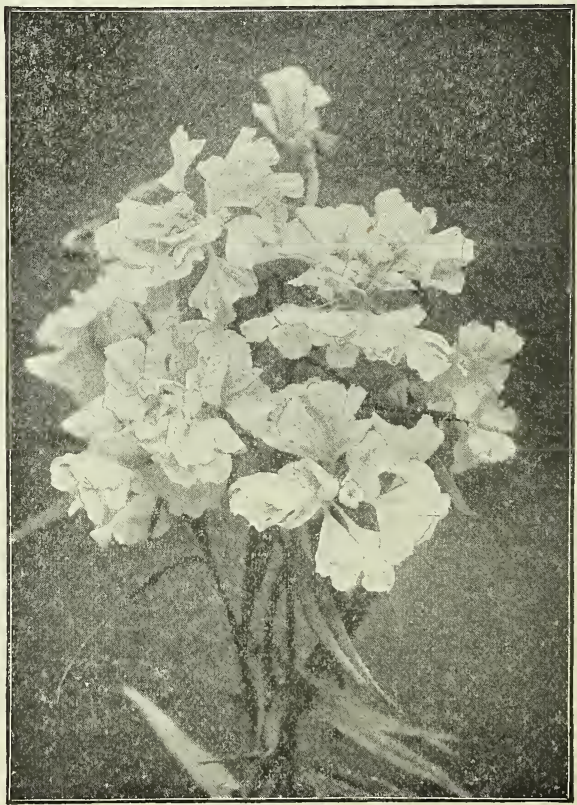

CLARKIA 
COCKSCOMB.

A half-hardy annual, growing 6 to 8 inches high, bearing a wide wavy blossom that resembles a cock's comb. Brilliant colors and fine for massing or border work.

Choicest Dwarf, mixed varieties, . . .10

\section{Cosmos.}

A tender annual, with fine cut feathery foliage and large feathery blossoms. Grows 4 to 6 inches high and blooms late in fall. Sow about May 1 st and transplant in late May or June.

Choice Mixed Varieties.

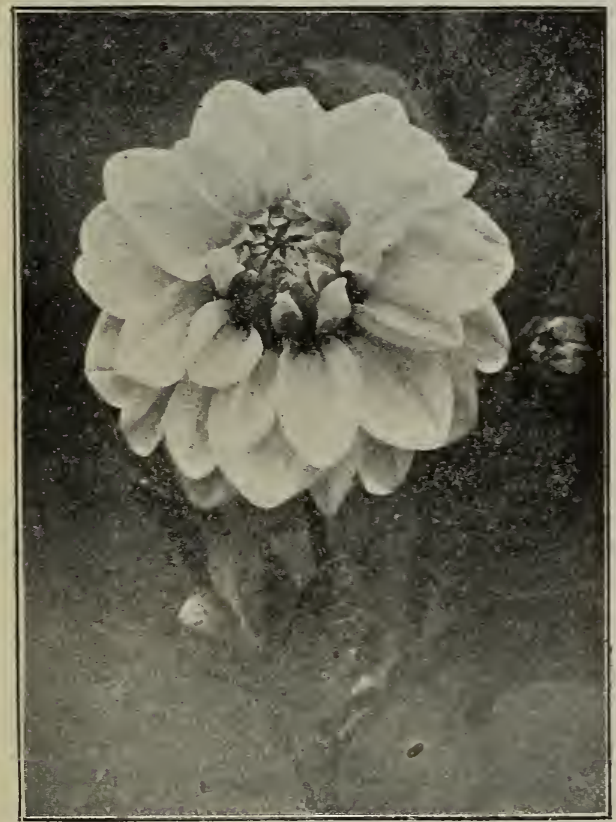

DAHLIA

\section{DAHLIA.}

A well known and popular late summer and autumn flowering plant. Seed may be sown early in hot bed and plants transplanted in May after all danger of frost is over. By sowing the seed early the plants may be made to bloom the first year.

Single (extra choice mixed), . • . .10

Double (large flowering, finest mixed), . . .15

\section{DIANTHUS (Pinks.)}

Hardy annual about one foot high and bearing beautifully colored single and double blossoms in profusion all summer. Sow seed early in boxes and transplant, or sow in rows where the plants are to remain and thin.

Splendid Mixed Varieties.

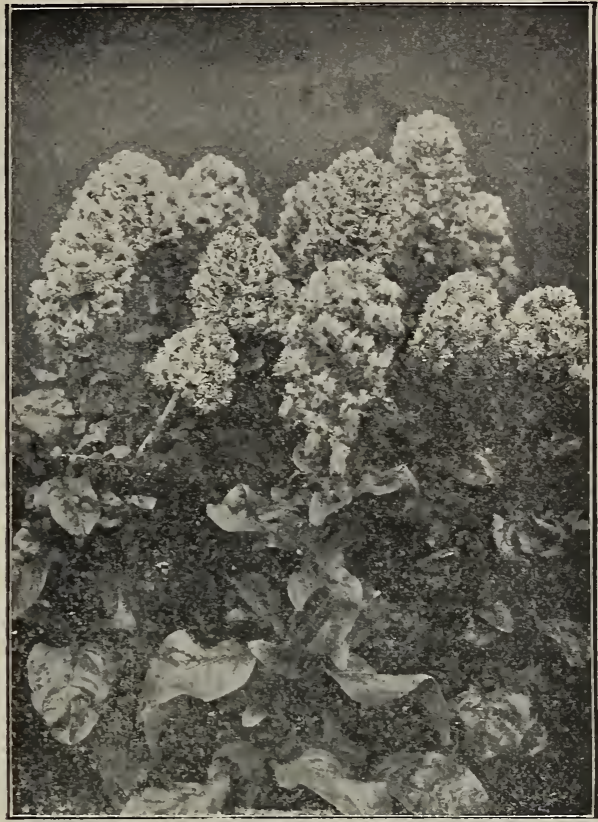

MIGNONETTE

(See page 28?

DIGITALIS. (Fox Glove).

A hardy perennial, blooming the second year from seed. Grows usually about $31 / 2$ feet high. The bell-shaped flowers are borne on long spikes and in shades of purple, lavender, rose and white. All spotted lightly inside the blossom. Thrives best in cool, shady locations.

Best Mixed Varieties,

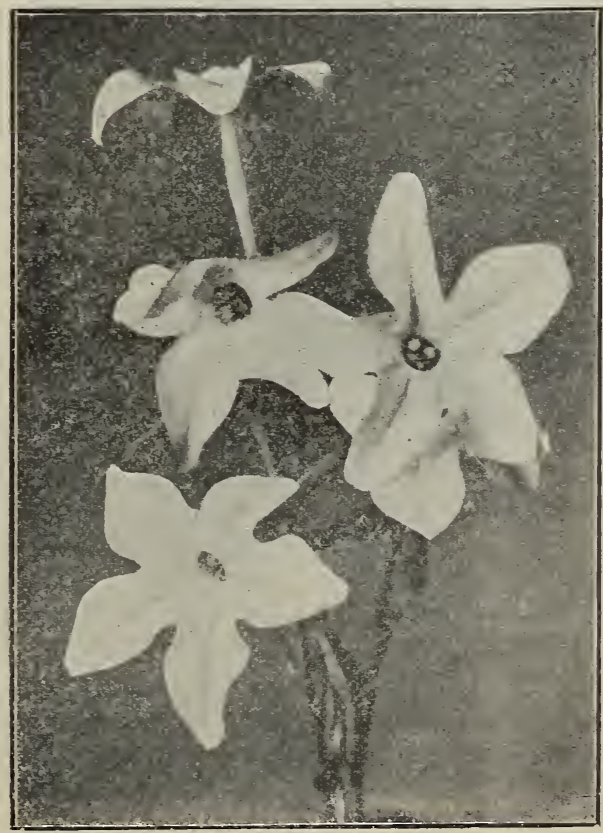

NICOTIANA

(See page 29 


\section{GODETIA.}

Hardy annual of compact growth, 6 to 10 inches high, bearing a profusion of satin cupshaped flowers, valuable for bedding or massing. Sow seed early.

Duchess of Albany, . See page 32)

\section{HOLLYHOCK.}

A hardy perennial of upright, stately growth, 5 to 8 feet high. They make a fine row in the garden, or a fine background next to a building or high wall or fence.

Finest Double Mixed,

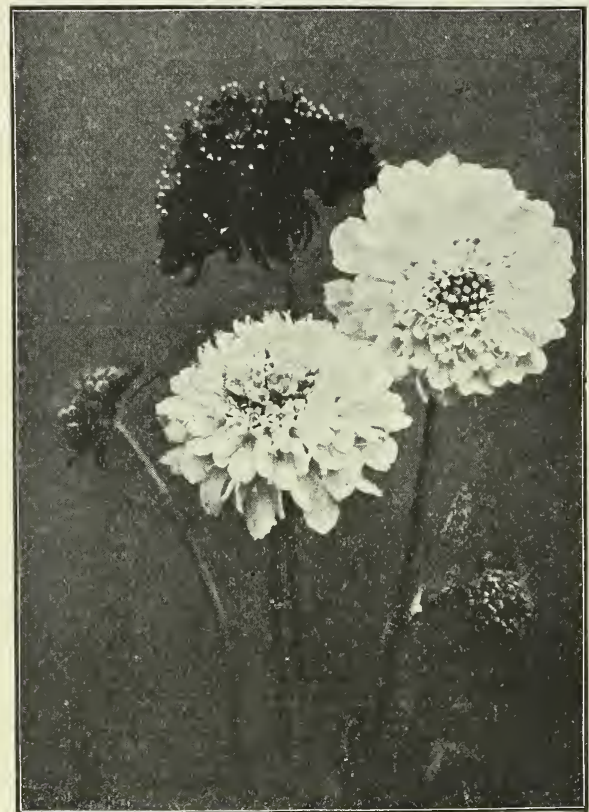

\section{SCABIOSA}

See page 29)

\section{MARIGOLD.}

A hardy annual shrub plant in dwarf and tall varieties, growing from 6 inches to 3 feet high. Foliage, bright green, deeply cut, and graceful. The flowers are various shades of yellow and brown. Tall varieties are valuable for large bedding or background work and the dwarf varieties for border.

Eldorado, mixed colors, (tall), . . . .05

Dwarf, gold striped, . . . . . .05

$$
\text { (See page 31) }
$$

\section{MIGNONETTE.}

A hardy annual, growing 6 to 12 inches high and bearing pyramidal-shaped flower spikes, which are made up of thickly set flowerets; exceedingly fragrant. Grows easily from seed and can either be transplanted from boxes or sown in garden and thinned to 4 to 6 inches. Valuable for potting, bedding or bordering.

Large Flowering,

Machet (fine selected stock), ${ }^{\cdot} \quad \cdot \quad \cdot \quad .05$
Pkt.

\section{VASTURTIUM.}

Prt.

Tender annual in two distinct classes, Dwarf and Tall or Climbing.

Dwarf (finest mixed colors), oz. $10 \mathrm{c} .1 / 4 \mathrm{lb} .15 \mathrm{c}$. Tall (finest mixed colors), . oz. 10 c. $1 / 4$ lb. $15 \mathrm{c}$.

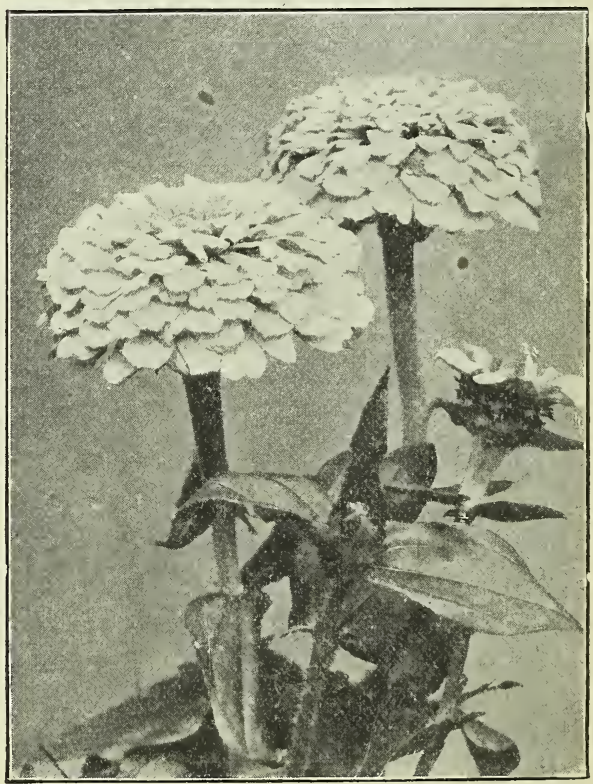




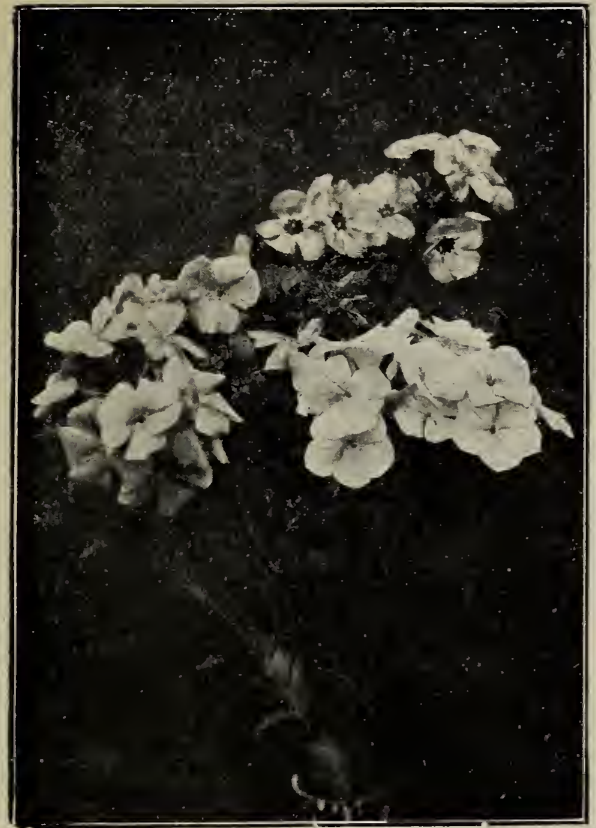

PHLOX .

NICOTIANA.

A half-hardy annual, growing about 3 teet high. Belongs to the tobacco family, has white blossoms, needs plenty of room.

Affinis,

$$
\text { (See page 27) }
$$

\section{PANSY.}

A half-hardy perennial, growing 4 to 6 inches high. It thrives best in a moist, shady location and in rich loamy soll. Seed should be sown in autumn for early spring blossoms. While the plants carry over well with a little covering during the winter, it is best to plant the seed anew each year.

Large French Strain, choice mixture,

\section{PETUNIA.}

A tender perennial. Adapted for greenhouse and pot culture and for open air, succeeding well in most any rich soll. Abundance of brilliant flowers during the season.

Extra Choice Mixed,

$$
\text { (See page 32) }
$$

\section{PHLOX DRUMMONDII.}

A hardy annual, growing from 6 to 10 inches high and bearing beautiful soft petaled and brilliantly colored, flowers all spring and summer. Fine for bedding. Sow seed about May 1st.

Choice Mixed,
POPPY.

A hardy annual, 3 to 5 feet high and bearing single and large double blossoms in bright colors. Sow seed in open ground where plants are to remain and thin to 6 or 12 inches.

White Swan, (a large double white flower), .05 The Shirley Mixed, (large single flower), . .05

\section{PORTULACA.}

Low growing or creeping annual, six to eight inches high and bearing glossy cup shaped blossoms in brilliant and gorgeous colors. The seed germinates slowly and should be started under glass.

Double Mixed,

SCABIOSA or Morning Bride.

Also called S weet Scabious, Old Maid's Pincushion, etc. A hardy annual, growing 8 inches to 2 feet high, and bearing heads of bright flowers on long slender stems. Very effective as a bedding plant, or for cut flowers.

Tall Mixed German Double,

\section{SALPIGLOSSIS.}

A half-hardy annual, about 3 feet high, bearing trumpet shaped blossoms of rich shades and colors, vasuable for bedding or massing also for cut flowers. Sow seed early and transplant or thin to 6 or 8 inches.

Choice Mixed,

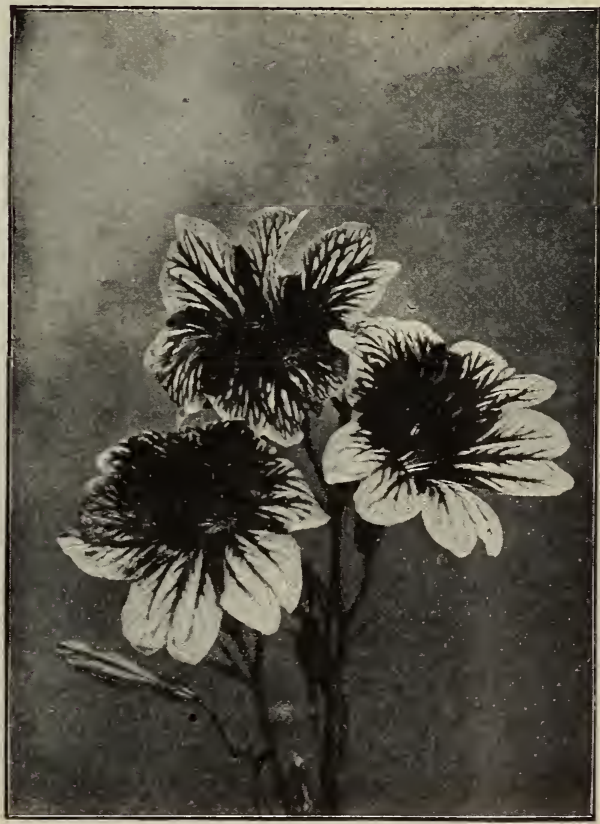

SALPIGLOSSIS 
SALVIA. (SCARLET SAGE.)

A tender perennial, blooming the first season from seed and growing 2 to 3 feet high. The blossoms are borne on long stems or spikes and are fragrant. The plant forms a bunch filled with bright scarlet blossoms.

Splenden

\section{STOCKS OR GILIFLOWER.}

Hardy annual, two feet high. The flowers are of many colors and very valuable for bedding and cut flowers. Sow seed in hot-bed or box and transplant.

Dwarf German Mixed,

Large Flowering Mixed,

\section{SWEET PEAS.}

The Sweet Pea is a climbing annual and hardy. This popular flower is of the easiest culture and well adapted to most any climate. The seed should be sown early in the spring in a drill 4 to 6 inches deep. dropping three or four seeds every four inches and covering about one inch, working the soil around the plant as it comes up until it is on a level with the surface, this leaves the roots down deep enough not to be affected by dry weather.

Sweet Peas require an abundance of water and an open location. The water should be applied at the roots and the vines should not be sprinkled. A trellis of brush or chicken wire is necessary.

$$
\text { (See page 28) }
$$

Pkt. Apple Blossom; crimson, pink and white shaded.

Aurora; orange, rose striped or white.

Blanche Burpee; pure white, (white seeded)

Countess of Cadogan; purple changing to lilac and blue.

Countess of Rađnor; lavender.

Emily Eckford; rose, lilac and blue.

Fascination; standard lilac, Fings tinged with lilac.

Her Majesty; rose crimson.

Hon. Mrs. E. Kenyon; large primrose.

Lady Grisel Hamilton; light shaded lavender.

Lottie Eckford; whiteshaded lilac and blue.

Lovely; deep pink, shading to light pink.

Miss Wilmot; large orange, pink.

Navy Blue; navy and light blue.

Othello; deep maroon.

Prima Donna; pure pink.

Prince of Wales; purple wings, blue striped or white.

Sadie Burpee; white buds tinged with pink.

Salopian; bright red.

Venus; light pink and buff blended.

Price, any above variety,

Finest Mixed Colors,

Eckford's Superb or Mixed,

$\begin{array}{lll}\text { oz. } & 3 / 4 \mathrm{lb} & 1 \mathrm{~b} . \\ 8 \mathrm{c} . & 15 \mathrm{c} . & 40 \mathrm{c} . \\ 5 \mathrm{c} . & 15 \mathrm{c} . & 25 \mathrm{c} . \\ 5 \mathrm{c} . & 15 \mathrm{c} . & 30 \mathrm{c} .\end{array}$

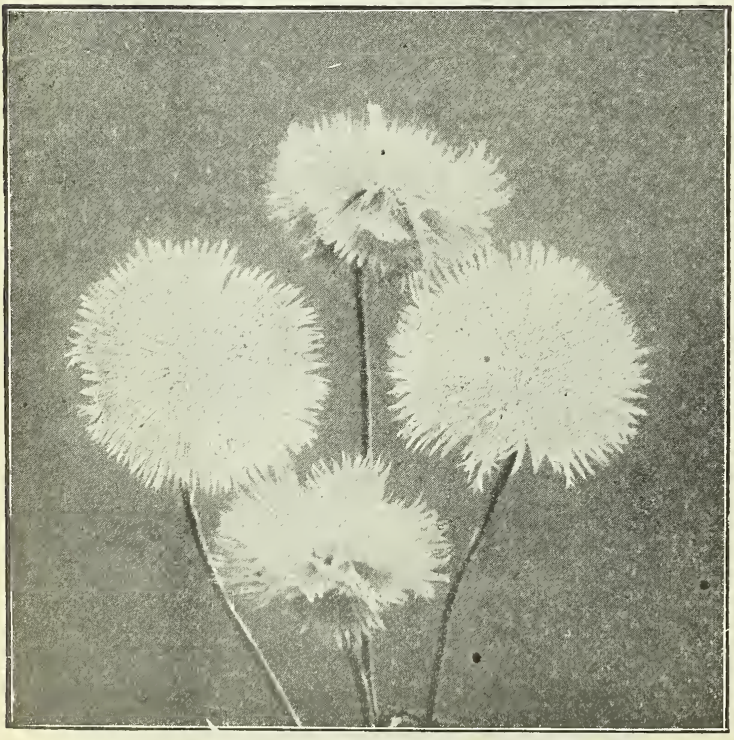

CENTAUREA

(See page 26)

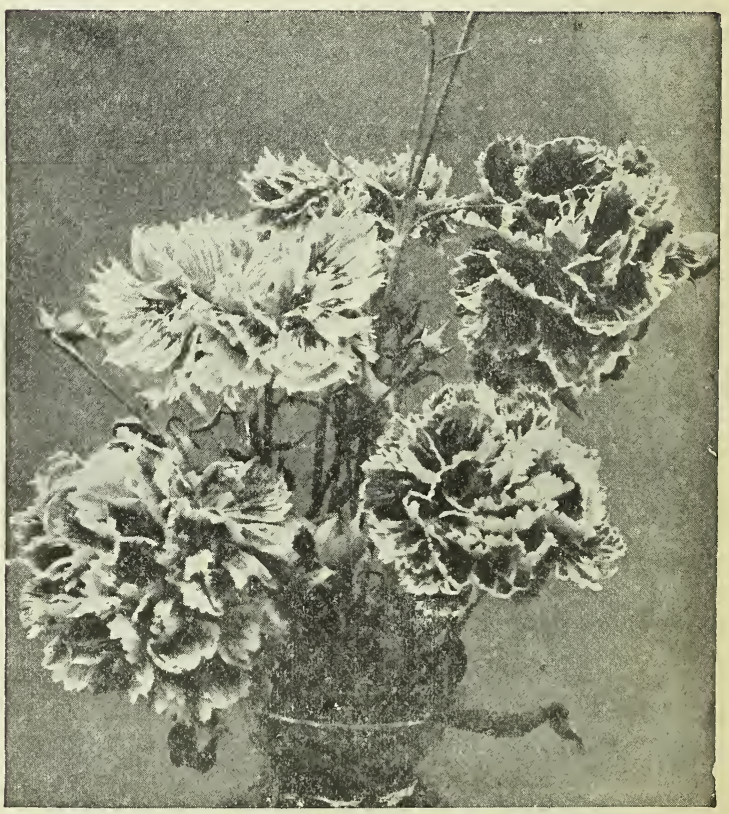

DIANTHUS

(See page 27) 
SWEET WILLIAMS.

A hardy perennial, blooming the second year from seed. Grows 1 to 2 feet high and bears its flowerets in clusters at end of a stiff stem. The individual flowers are handsomely colored and marked. It makes a beautiful bedding plant, and is of easy culture.

Double Finest Mixed,

\section{VERBENA.}

A half hardy trailing perennial of easy culture. It is well known as a bedding or border plant and is also used to some extent for cut flowers.

Henderson Mammoth, finest mixed,
Pkt.

\section{ZINNLA.}

A half-hardy annual, growing from 1 to 2 feet high. Blossoms are very double and while the stems are stiff they make an excellent bouquet flower. The colors are in great variety and very bright. Probably no flower has such an assortment of shades, tints and colors, and no bedding plant is more effective for a brilliant show. Sow in boxes early and tiansplant.

Double Fine Mixed, .

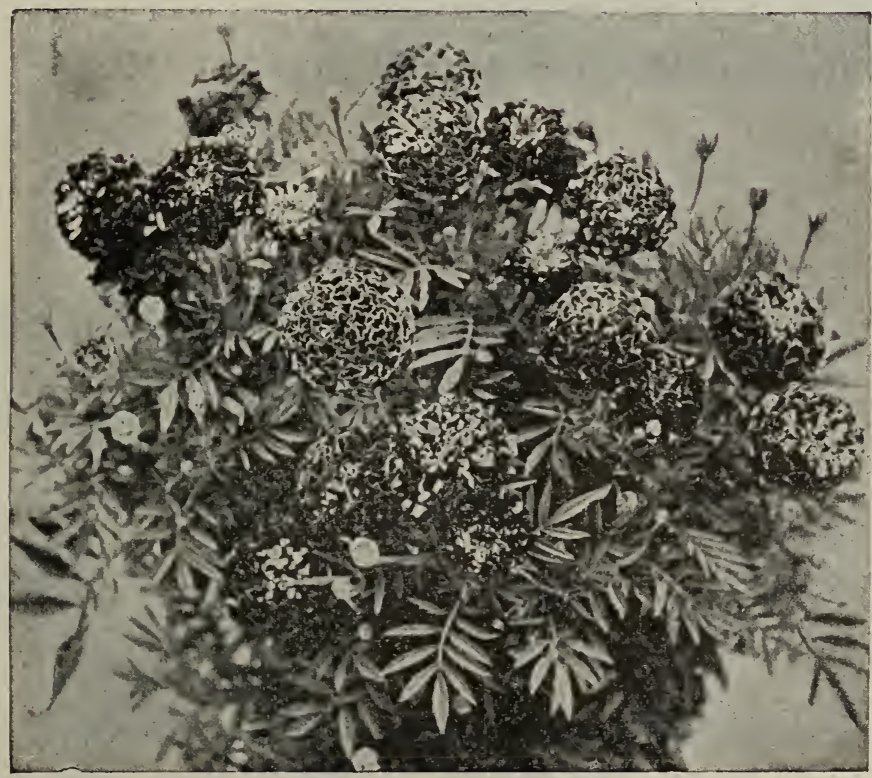

MARIGOLD

(See page 28.) 



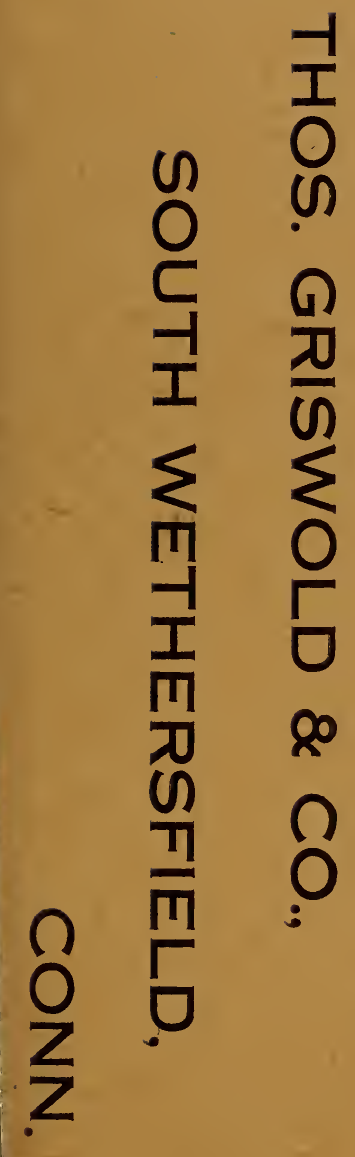



$\left.\frac{8}{2}\right|_{-\infty} ^{\frac{5}{2}}$

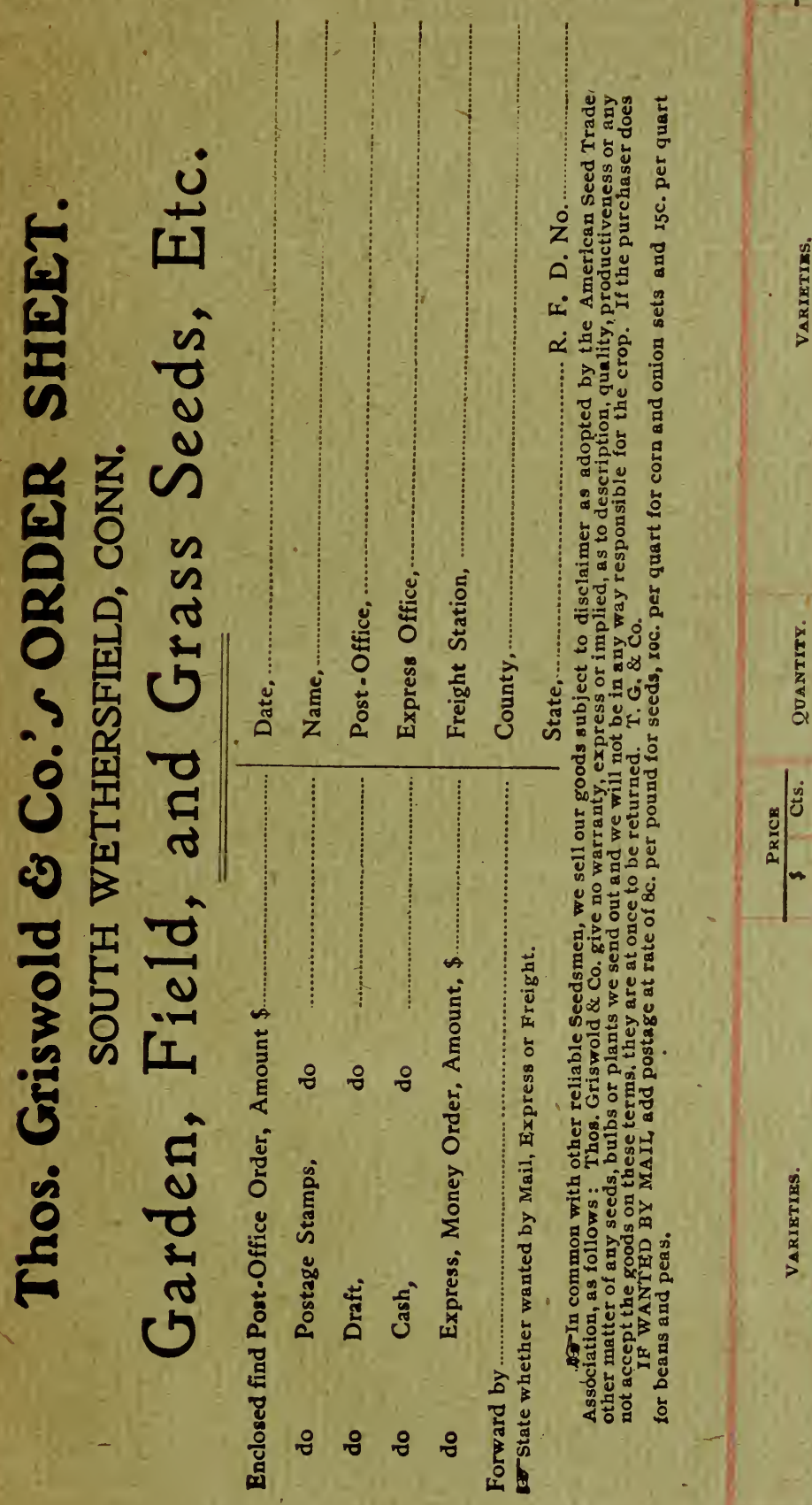

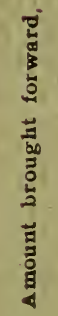

$\frac{\dot{g}}{8}$

$\stackrel{\substack{a \\ a}}{a}$ 



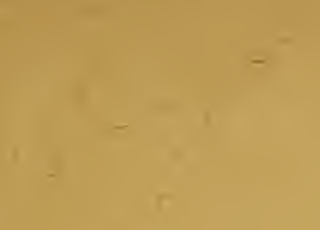

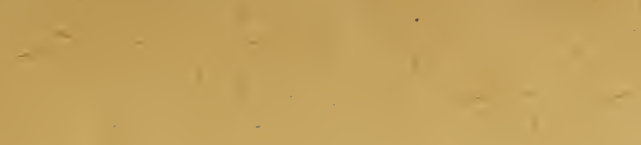

.
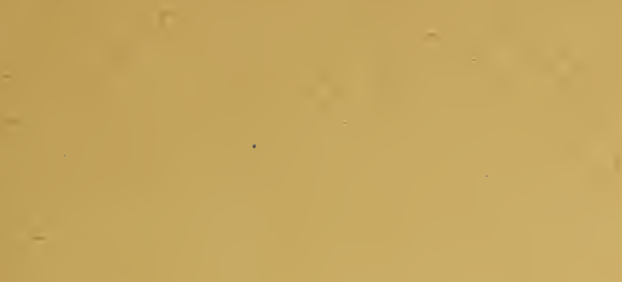

(1-

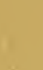

1.

, '
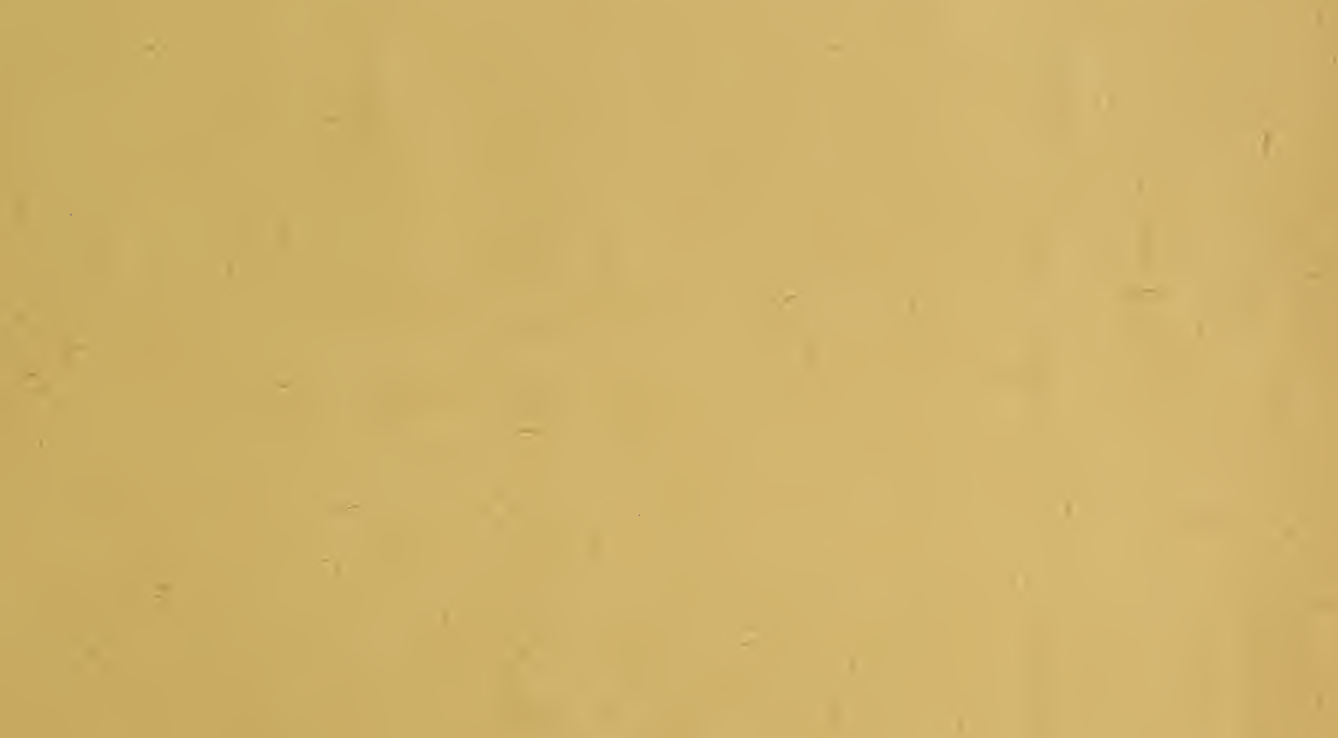

s

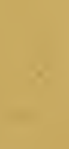




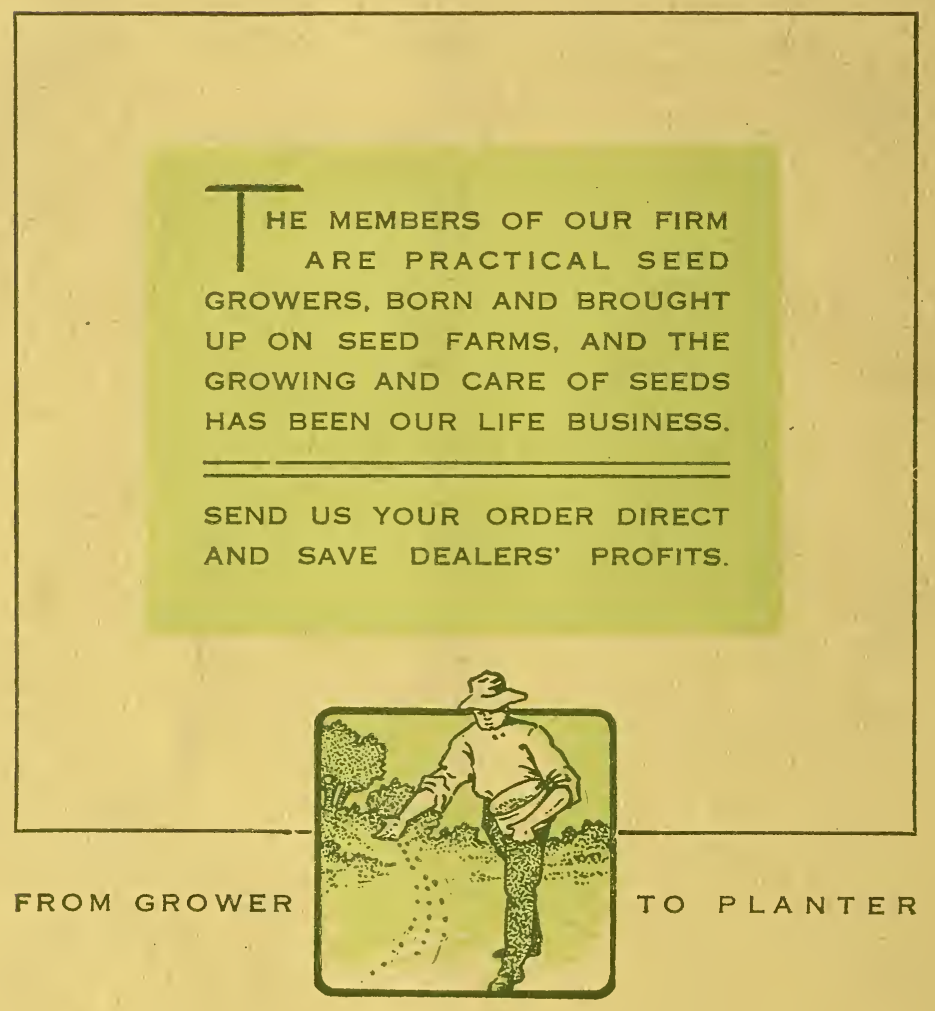

